University of Rhode Island

DigitalCommons@URI

Open Access Master's Theses

1986

\title{
Water Use and Drought Responses of Cool-Season Turfgrasses
}

Lisa J. Aronson

University of Rhode Island

Follow this and additional works at: https://digitalcommons.uri.edu/theses

\section{Recommended Citation}

Aronson, Lisa J., "Water Use and Drought Responses of Cool-Season Turfgrasses" (1986). Open Access Master's Theses. Paper 1418.

https://digitalcommons.uri.edu/theses/1418

This Thesis is brought to you for free and open access by DigitalCommons@URI. It has been accepted for inclusion in Open Access Master's Theses by an authorized administrator of DigitalCommons@URI. For more information, please contact digitalcommons-group@uri.edu. 


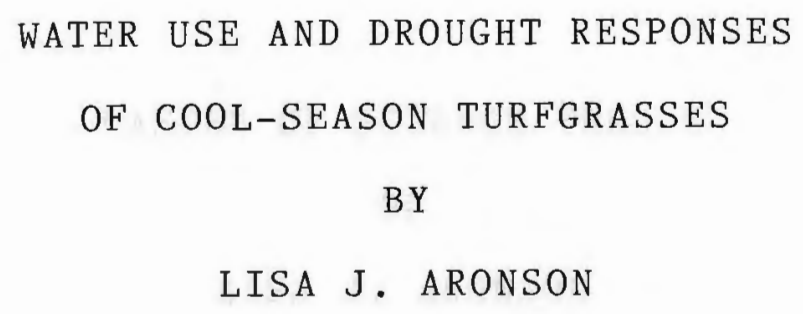

A THESIS SUBMITTED IN PARTIAL FULFILLMENT OF THE REQUIREMENTS FOR THE DEGREE OF

MASTER OF SCIENCE

IN

PLANT SCIENCE

UNIVERSITY OF RHODE ISLAND

1986 
MASTER OF SCIENCE THESIS

OF

LISA J. ARONSON

APPROVED :

Thesis Committee Major Professor

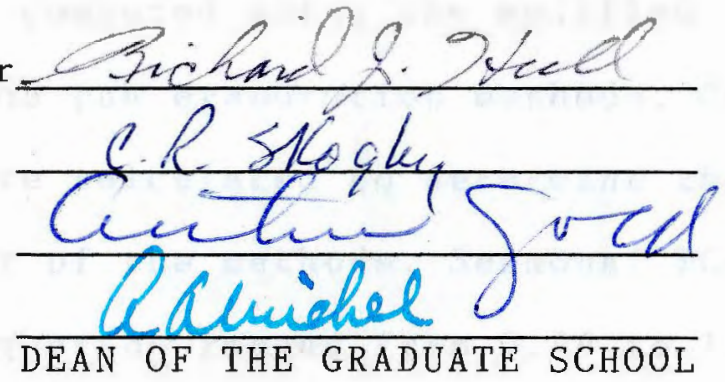


Evapotranspiration (ET) rates of four turfgrass species were compared in Rhode Island to aid in the selection of grasses with lower water requirements. ET was measured under we11-watered conditions using weighing lysimeters placed into field plots of mature turf. Measurements were obtained regularly from July to September in 1984 and 1985. Average daily ET ranged from 0.23 to $0.41 \mathrm{~cm}$ of water/day for: Poa pratensis L. cvs. 'Baron' and 'Enmüni', Lo1ium perenne L. cv. 'Yorktown II', Festuca rubra var. commutata Gaud. cv. 'Jamestown', and Festuca ovina var. duriuscula L. Koch cv. 'Tournament'. Significant differences in ET rates were found between species. Kentucky bluegrass and perennial ryegrass transpired more than the fescues.

Potential ET was computed using the modified Penman equation and the pan evaporation methods. Crop coefficients (KCs) were calculated to determine the predictive consistency of the methods. Seasonal KCs based on the Penman equation ranged from 0.88 to 1.09 . KCs based on pan evaporation showed more variability, ranging from 0.86 to 1.35 . 
The response of the same turfgrasses to moisture stress was investigated. Six lysimeters of each species and six we11-watered control 1ysimeters were included in a greenhouse study; four 1ysimeters of each were used in a field study. The relationship between water loss due to ET and soil water potential was determined using tensiometers and electrical resistance blocks installed in separate lysimeters.

ET rates of all species remained unaffected by decreasing soil water potential until it reached -0.6 to -0.8 bars, after which ET rates declined. This decline corresponded to a decline in turf quality, growth rate, and relative leaf water content. Leaf water potential decreased $50-75 \%$ when soil water potential declined to -0.8 bars but did not continue to decrease when soil water potential became more negative. No consistent increase in canopy temperature was noted until available soil water approached permanent wilting point.

Kentucky bluegrass and perennial ryegrass showed the most rapid response to moisture stress. Hard fescue was the most drought tolerant of the four species. 


\section{ACKNOWLEDGEMENTS}

I want to thank Dr. Richard Hu11, Dr. Arthur Gold, and (the hopefully to be) Dr. John Cisar for all their help and support. Of course, many thanks also to Susan, Annamarie, Eric, Matt and the rest of the bucket brigade for all the work they did. Emery LaFreniere deserves special recognition and thanks for his engineering assistance. And many thanks to David for his patience and support.

The research on which this thesis was based was financed in part by the U.S. Department of the Interior Geological Survey through the Rhode Island Water Resources Research Center. 


\section{PREFACE}

This thesis is written in manuscript

format as specified by Agronomy Journal 
Abstract.......................

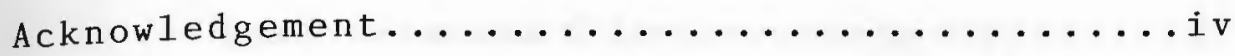

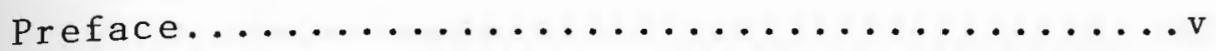

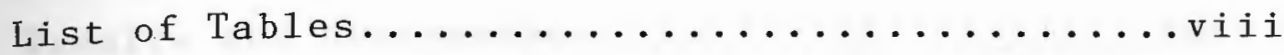

List of Figures..................

Manuscript I: Turfgrass Water Use Under We11-Watered Conditions........

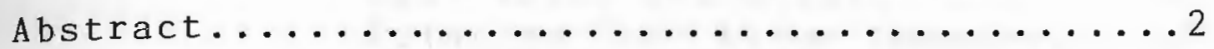

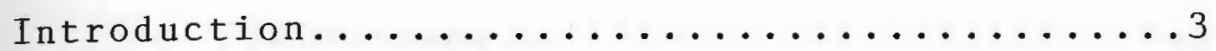

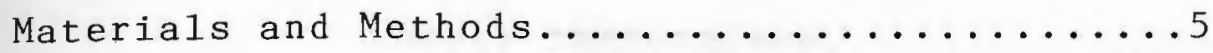

Predictive Methods..............

a) Penman equation method......

b) pan evaporation method.......9

Results and Discussion.................

Actual evapotranspiration..........10

Potential evapotranspiration........17

a) Penman equation method......17

b) pan evaporation method......18

Conclusion.......................... 44

Literature Cited.................... 5

Manuscript II: Turfgrass Response to

Drought Stress............28

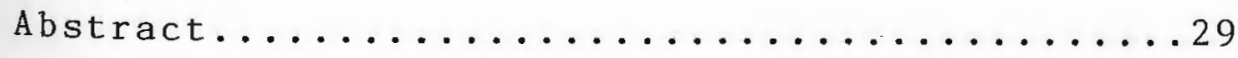

Introduction...................... 
Materials and Methods..................... 33

Greenhouse study...............33

Soil Moisture Characteristic Curve...36

Field study....................

Results and Discussion................. 39

Greenhouse study................39

Evapotranspiration rates......39

Turf Quality and Growth rate...40

Leaf Water Potentia1........44

Relative Leaf Water Content....45

Field study............... 48

Canopy temperature.........49

Conclusion........................

Literature Cited................. 52

Appendix I: Literature Review........... 54

a) We11-watered study............54

b) Drought stress study ...........59

Bibliography...................66 
Table 1

Tab1e 2

$\underline{\text { Tab1e } 3}$

$\underline{\text { Tab1e } 4}$

$\underline{\text { Table } 5}$

$\underline{\text { Tabie } 6}$

$\underline{\text { Tab1e } 7}$

$\underline{\text { Tab1e } 8}$
Mean daily and seasonal ET rates of 5 turfgrasses in we11-watered condition in 1984 and $1985 \ldots \ldots \ldots \ldots \ldots 12$

Monthly precipitation and departure from the norm in Kingston,R.I. in 1984 \& $1985 \ldots \ldots 13$

Mean maximum air temperature and mean solar radiation in Kingston, R.I. in 1984 \& $1985 \ldots \ldots 14$

Average canopy density and LAI of five turfgrasses in $1984 \ldots 15$

Average seasonal crop coefficients based on the Penman equation in $1984 \& 1985 \ldots \ldots \ldots \ldots 20$ Average biweekly crop coefficients based on the Penman equation in $1984 \& 1985 \ldots \ldots \ldots \ldots 21$

Average seasonal crop coefficients based on the pan evaporation method in $1984 \& 1985 \ldots .22$

Average biweek $1 \mathrm{y}$ crop coefficients based on the pan evaporation method in $1984 \ldots \ldots \ldots 23$ 
Figure 1

Evapotranspiration rates of

4 turfgrasses in the greenhouse undergoing drought stress........41

Figure 2

Quality ratings of 4 turfgrasses in the greenhouse subject to declining soil water potential....44

Figure 3

Leaf growth rate of 4 turfgrasses in the greenhouse subject to declining soil water potential....443

Figure 4

Leaf water potential of 4 turfgrasses in the greenhouse subject to declining soil water potentia1..46

Figure 5

Relative leaf water content of 4 turfgrasses in the greenhouse subject to declining soil water potential.................47

Figure 6 Canopy temperature of 4 turfgrasses in the field, subject to declining soil water potential..........50 
TURFGRASS WATER USE

UNDER

WELL-WATERED CONDITIONS 


\section{ABSTRACT}

Evapotranspiration (ET) rates of four turfgrass species (five cultivars) were compared in Rhode Island to aid in the selection of grasses with lower water requirements. ET was measured under we11-watered conditions using weighing lysimeters placed into field plots of mature turf. Measurements were obtained regularly from July to September in 1984 and 1985. Average daily ET ranged from 0.23 to $0.41 \mathrm{~cm}$ of water per day for the five grasses: Poa pratensis L. cvs. 'Baron' and 'Enmundi', Lolium perenne L. cv. 'Yorktown II', Festuca rubra var. commutata Gaud. cv. 'Jamestown', and Festuca ovina var. duriuscula L. Koch cv. 'Tournament'. Significant differences in ET rates were found between species, with Kentucky bluegrass and perennial ryegrass having higher ET rates than either of the fescues.

Potential ET was computed from daily meteorological data using two predictive methods; the modified Penman equation method, and the pan evaporation method. Crop coefficients (KCs) were then calculated in order to determine the consistency with which these two methods predict measured ET on a seasonal and biweekly basis. Seasonal KCs based on the Penman equation method ranged from 0.88 to 1.09 (C.V. ranged $14.5 \%$ - 29.6\%). Seasona1 KCs based on the pan evaporation method were more variable, ranging from 0.86 to 1.35 (C.V. ranged $33.8 \%-44.6 \%$ ). 


\section{INTRODUCTION}

Turfgrass maintenance can require the use of much irrigation water, even in the humid northeastern U.S. As competition for water use increases, turfgrass culture must be directed toward practices that will lower water requirements.

Transpiration accounts for most of the water lost from a dense turfgrass canopy (1). It has been previously established that transpiration rate varies among turfgrass species $(1,2,5,14,16)$. Despite the growing attention being focused on turf water use, little research has been directed to measuring water use by the cool-season grasses grown in the northeast. Drought conditions do occur periodical1y during most growing seasons, and restrictions on water availability for turf irrigation are no longer isolated to the arid regions of the country. Knowledge of the water use rates of turfgrasses in the northeast is necessary to identify grasses with lower water requirements, and to design and utilize irrigation systems for maximum water use efficiency.

Information on the evapotranspiration (ET) rates of these turfgrasses also allows for the computation of crop coefficients (KCS), the ratio between measured ET (ETa) and potential ET (ETo) derived from a predictive method. Methods which predict crop water use on the 
basis of climatic conditions are frequently used for irrigation scheduling because accurate field measurements are difficult to obtain. These methods predict the water use of a standardized reference crop (ETo) which is defined as "the rate of evapotranspiration from an extensive surface of 8 to $15 \mathrm{~cm}$ tall green grass cover of uniform height, actively growing, completely shading the ground and not short of water" (4). Crop coefficients are used to calibrate reference ET values for specific crop and climatic conditions (4).

The goal of this study was to quantify and compare water use of four species (five cultivars) of cool-season turfgrasses maintained under well-watered conditions. Crop coefficients were computed from these data based on two predictive methods (the modified Penman equation and pan evaporation) to determine how consistent1y these methods predict turfgrass evapotranspiration in the northeast. 
MATERIALS and METHODS

Evapotranspiration (ET) rates of four species (five cultivars) of cool-season turfgrasses were monitored for two seasons under well-watered conditions (soil water potential above -0.4 bars). ET rates were measured by determining the mass loss of weighing lysimeters containing $15 \mathrm{~cm}$ deep undisturbed sod/soil cores taken from turf swards established in 1980. Four replicate lysimeters were contructed using the following: Poa pratensis L. cvs. 'Baron' and 'Enmundi', Lolium perenne L. cv. 'Yorktown II', Festuca rubra var. commutata Gaud. cv. 'Jamestown', and Festuca ovina var. duriuscula L. Koch cv. 'Tournament'. The plots were established at the Turfgrass Research Farm of the University of Rhode Island Agricultural Experiment Station. The soil is an Enfield silt loam (coarse silty over sandy skeletal, mixed, mesic Typic Dystrochrept). In 1984, each lysimeter was placed in a $1.8 \times 2.4 \mathrm{~m}$ field plot of the same species which was established at the same time the turf from which the lysimeter cores were taken. In 1985, four additional lysimeters of each species were constructed using cores taken from the same plots used in the 1984 study. Single plots $(6.7 \times 7.6 \mathrm{~m})$ of each species, seeded in October of 1984, were divided into ten 3.4 x $1.5 \mathrm{~m}$ subplots. Lysimeters were placed in the center four subplots. 
The lysimeters were patterned after those used by Feldhake et a1. (8) for turfgrass ET studies. They were constructed from polyethylene buckets, $25.4 \mathrm{~cm}$ in diameter and $23 \mathrm{~cm}$ deep, each containing a $15 \mathrm{~cm}$ deep undisturbed sod and soil core resting on $7.6 \mathrm{~cm}$ of a $1: 1$ native soil:perlite mix. Five drainage holes at the base of each bucket were covered with metal screening to prevent soil 10ss. The $15 \mathrm{~cm}$ depth of the sod/soil core was expected to include the majority of the turf root system. A layer of gravel was placed in each lysimeter hole to ensure adequate drainage. A polyethylene sleeve was used to line the side of each hole and facilitate removal of the lysimeters for weighing.

The lysimeters were weighed at 24 hour intervals to determine water loss due to ET. The balance used ( $O^{\prime H}$ Has $20 \mathrm{~kg}$ solution balance) provided accuracy to the nearest gram (equivalent to $0.02 \mathrm{~mm}$ of water). In 1984, 35 24hour measurements were obtained from each of the 20 1ysimeters and 40 24-hour measurements were obtained from each lysimeter in 1985.

To maintain wel1-watered conditions, the 1ysimeters and the surrounding plots were irrigated, and soil restored to field capacity ( 24 hour drainage after irrigation) every four-to-five days if no precipitation had occurred. In 1985, an additional lysimeter of each turfgrass containing a tensiometer installed at a depth of 
$10 \mathrm{~cm}$ was included in each plot to monitor soil water potential.

Predictive Methods

Two predictive methods, the modified Penman equation and pan evaporation, were used to compute potential ET and were evaluated for their predictive consistency. Crop coefficients (KCs) were calculated from both methods as the ratio between actual ET (ETa) and predicted ET (ETo) .

$$
\mathrm{KC}=\mathrm{ETa} / \mathrm{ETO}
$$

The consistency of the relationship between actual and predicted ET determines the usefullness of the predictive method as a tool for estimating crop water use and scheduling irrigation.

A) The modified Penman equation $(3,15)$ is a combination of an energy balance and an aerodynamic term. As a predictive method, the equation is well-grounded in theory and, with the use of high speed computers, it can be relatively easy to use. The equation requires the input of eight daily weather variables, which necessitates proximity and access to a well-instrumented weather station. A simplified version of the Penman equation has recently been developed which can closely approximate reference ET with fewer, more readily attainable inputs (12). 
For this paper, the conventional form of the modified Penman equation was used:

$E T=\frac{\Delta}{\Delta+\gamma}(R n+G)+\frac{\gamma}{\Delta+\gamma} 153.6 W_{f}\left(e_{a}-e_{d}\right)$

where:

$E T$ = evapotranspiration in energy units $\left(\mathrm{J} / \mathrm{m}^{2}-\mathrm{d}\right)$ [converted to $\mathrm{mm}$ of water by dividing by the heat of water].

$\Delta=$ the slope of the vapor pressure-temperature curve $(\mathrm{kPa} / \mathrm{K})$.

$\gamma=$ the psychrometric constant $(\mathrm{kPa} / \mathrm{K})$.

$\mathrm{Rn}=$ net radiation $\left(\mathrm{J} / \mathrm{m}^{2}-\mathrm{d}\right)$.

$G=$ soil heat flux [positive toward the ground surface] $\left(\mathrm{J} / \mathrm{m}^{2}-\mathrm{d}\right)$.

$\mathrm{e}_{\mathrm{a}}=\begin{aligned} & \text { saturation vapor pressure at mean air temperature, } \\ & \mathrm{kPa} \text {. }\end{aligned}$

$e_{d}=$ saturation vapor pressure at dewpoint, $\mathrm{kPa}$.

$W_{f}=$ wind function.

Solar radiation data, derived from a standard Pyrheliometer, were provided by the Eppley laboratory in Newport, R.I., located $20 \mathrm{~km}$ from the plot area. Extraterrestrial radiation values for each month were obtained for $40^{\circ} \mathrm{N}$ latitude (4). A11 other meteorologic inputs were collected from the RIAES weather station located $200 \mathrm{~m}$ from the experimental plots. A standardized albedo value of 0.23 was used in all calculations. 
B) The pan evaporation method is based on the assumption that evaporation from a specific open water surface provides a standard measurement of the combined effect of temperature, radiation, wind and humidity, which can be used to predict crop water use. Evaporative loss from a standard Weather Bureau Class A pan (Epan) is related to reference crop ET (ETo) by an empirically derived coefficient (Kp) which accounts for wind speed, relative humidity and pan environment (4).

$$
\mathrm{ETo}=\mathrm{Kp} \times \mathrm{Epan}
$$

The evaporation pan used to compute ETo in this study is surrounded by actively growing, well-watered grass approximately $100 \mathrm{~m}$ in all directions. With this arrangement, for example, with conditions of light wind $(<175 \mathrm{~km} /$ day $)$ and high humidity $(>70 \%)$, a pan coefficient of 0.85 was used. Under conditions of moderate winds $(175-425 \mathrm{~km} / \mathrm{day})$ and low humidity $(<40 \%)$ a $\mathrm{Kp}$ value of 0.65 was used (4).

All the data was subject to an analysis of variance for a completely randomized design using a general linear models procedure, SAS Institute, Inc. (18). Since dates are not randomly assigned within species, date was used as a subplot observation, rather than a replication, in the statistical analysis. 


\section{RESULTS and DISCUSSION}

I. Actual evapotranspiration:

Mean ET of all the grasses included in this study was $0.36 \mathrm{~cm}$ of water per day (2.5 cm/week). during the months of July through September. These values ranged from a minimum of $0.122 \mathrm{~cm}$ of water per day for hard fescue in September to a maximum of $0.748 \mathrm{~cm}$ of water per day for Kentucky bluegrass cv. 'Enmundi' in July. This is consistent with previously reported ET rates of cool-season turfgrasses. Average ET rates range between $0.26-0.76 \mathrm{~cm} /$ day $(1,5,17)$ although rates in excess of $1.14 \mathrm{~cm} / \mathrm{day}$ occur occasionally in hotter, less humid c1imates $(1,2,16)$.

Table 1 contains mean water use rates during 1984 and 1985. A11 five grasses used more water in 1985 than they did in 1984. In 1984 seasonal water use ranged from $27-42 \mathrm{~cm}$, while in 1985 it ranged from $43-49.7$ cm. This is probably due, in part, to the greater humidity and cloudiness which occurred in July of 1984. Table 2 contains monthly precipitation (cm of water) and the departure from the norm for Kingston, R.I. in 1984 and 1985. Mean maximum air temperatures $\left(C^{\circ}\right)$ and mean solar radiation (langleys/day) in 1984 and 1985 are shown in Table 3 . The values in Table 3 are based 
only on days that ET measurements were obtained.

The two cultivars of Kentucky bluegrass, 'Baron' and

'Enmundi', differed significantly in water use rates during both seasons. Differences in water use rates between Kentucky bluegrass cultivars were also reported by Shearman (19). In 1984, 'Baron' used significantly more water than any of the other grasses, while 'Enmundi' ranked intermediate. In 1985, 'Baron' used more water than it did in 1984 but ranked intermediate relative to the water use of the other grasses. 'Enmundi' had a significantly greater water use rate than the other grasses in 1985. Hard fescue used significantly less water than a11 other grasses throughout the 1984 season, but ranked intermediate in 1985 .

The general conclusion to be drawn from these data for the two seasons is that Kentucky bluegrass cv. 'Enmundi' and perennial ryegrass use more water than either of the fine fescues. The decreased density and vigor of the Kentucky bluegrass cv. 'Baron' sod in 1985, based on visual inspection, may have contributed to the comparative change noted in its water use rates between the two seasons.

When soil water is readily available, turfgrass water use is usually assumed to be governed primarily by conditions external to the plant $(5,7,11,20)$. Many 
Table 1. Mean daily and seasonal evapotranspiration (ET) rates of five cool-season turfgrasses maintained in well-watered conditions in 1984 and 1985 (field study).

\begin{tabular}{|c|c|c|c|c|c|c|c|}
\hline \multirow{2}{*}{\multicolumn{2}{|c|}{ Species }} & \multicolumn{3}{|c|}{1984} & \multicolumn{3}{|c|}{1985} \\
\hline & & an dail & $\mathrm{ET}$ & son tota 1 & an dail & $\mathrm{ET}$ & season total \\
\hline & & & $(\mathrm{cm}$ & & & $(\mathrm{cm}$ & $0)$ \\
\hline $\mathrm{KBb}$ & 8 & 0.350 & $a^{*}$ & 42.0 & 0.365 & c & 43.8 \\
\hline $\mathrm{KBe}$ & & 0.338 & $\mathrm{~b}$ & 40.6 & 0.414 & $\mathrm{a}$ & 49.7 \\
\hline PR & & 0.340 & $\mathrm{~b}$ & 40.8 & 0.396 & $\mathrm{~b}$ & 48.5 \\
\hline $\mathrm{RF}$ & & 0.338 & $\mathrm{~b}$ & 40.6 & 0.358 & d & 43.0 \\
\hline $\mathrm{HF}$ & & 0.225 & c & 27.0 & 0.393 & $\mathrm{~b}$ & 48.2 \\
\hline
\end{tabular}

* Means followed by the same letter are not significant1y different at the 5\% level based on Duncan's Multiple Range test.

$\S \mathrm{KBb}=$ Kentucky bluegrass $c v$. Baron

$\mathrm{KBe}=$ Kentucky bluegrass cv. Enmundi

$\mathrm{PR}=$ perennial ryegrass

$R F=$ red fescue

$H F=$ hard fescue 
Month1y precipitation (cm of water) and departure from the norm in Kingston, R.I. in 1984 and 1985.

\begin{tabular}{lrr}
\hline Month & \multicolumn{1}{c}{1984} & \multicolumn{1}{c}{1985} \\
\hline July & $17.86(+10.26)$ & $7.39(-0.20)$ \\
August & $2.77(-8.56)$ & $32.28(+20.96)^{*}$ \\
September & $5.59(-5.31)$ & $6.99(-3.45)$ \\
Total & $26.22(-3.61)$ & $46.66(+17.31)$
\end{tabular}

* the majority of this precipitation occurred in a few intense storms concentrated at the end of the month. 
Table 3. Mean maximum air temperature $\left(C^{\circ}\right)$ and mean solar radiation (langleys/day) in Kingston, R.I. in 1984 and 1985.

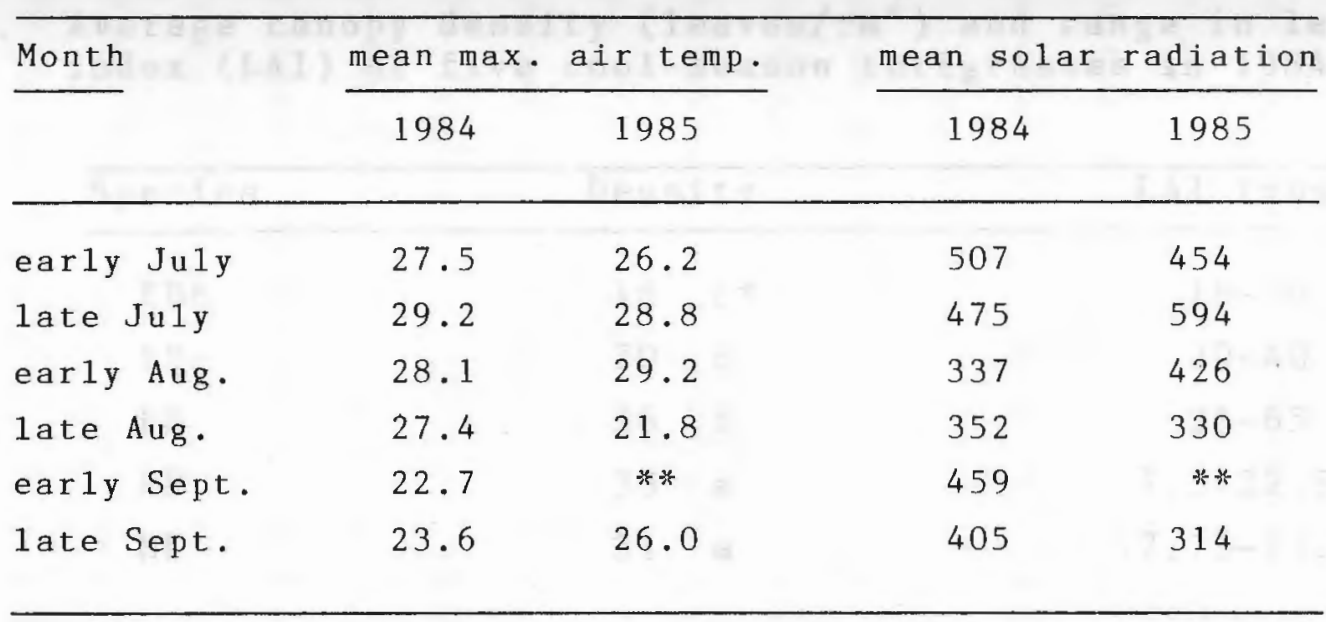

Mean values are based only on days that ET measurements were obtained.

** no ET measurements taken. 
Table 4. Average canopy density (leaves/ $\mathrm{cm}^{2}$ ) and range in leaf area index (LAI) of five cool-season turfgrasses in 1984 .

\begin{tabular}{lccc}
\hline Species & Density & LAI range \\
\hline $\mathrm{KBb}$ & $18 \mathrm{c}^{*}$ & $18-36$ \\
$\mathrm{KBe}$ & 20 & $\mathrm{c}$ & $20-40$ \\
$\mathrm{PR}$ & 26 & $\mathrm{~b}$ & $26-65$ \\
$\mathrm{RF}$ & 30 & $\mathrm{a}$ & $7.5-22.5$ \\
$\mathrm{HF}$ & 31 & $\mathrm{a}$ & $7.75-23.3$ \\
\hline
\end{tabular}

* Means followed by the same letter are not significantly different at the $5 \%$ level based on Dincan's Multiple Range test. 
reports on turfgrass ET under we11-watered conditions have concluded that ET is a function of meteorologic conditions and the extent of vegetative cover $(5,8,9)$. However, the significant differences in ET between species under identical climatic conditions and cultural practices found in this study indicate that water use may also be under genetic control. This will have further implications in plant breeding for maximum water use efficiency .

Differences in canopy density is one of several plant characteristics expected to influence water use rate. Increased density causes increased boundary layer resistance to convective air flow within the canopy (10). This resistance results in a reduced saturation vapor deficit surrounding the plants in a turf stand, thereby reducing the evaporative demand which drives ET (13).

Canopy density measured on the turfgrass stands in the 1984 lysimeters are presented in Table 4. Canopy density is inversely related to water use rate for the five grasses. Those which have the greatest transpiration rates, Kentucky bluegrass and perennial ryegrass, have lower leaf densities than the fescues, which were found to use less water. The size of the leaves and thus their potential for reducing convective air flow will also vary. Kentucky bluegrass leaves range from 
2 - $4 \mathrm{~mm}$ wide, perennial ryegrass leaves range from 2 $5 \mathrm{~mm}$ wide, and the fescue leaves range from $0.5-1 \mathrm{~mm}$ in width (1). The resulting differences in leaf area index (Table 4) between species will influence their water use rates by altering the boundary layer resistance of the canopy and well as alter the transpiring surface area.

II. Potential evapotranspiration:

Two predictive methods were assessed in this study for their ability to consistently estimate turf water use in southern New England.

A. The modified Penman equation method: Average seasonal crop coefficients (KCs), Table 5, ranged from 0.88 for hard fescue in 1984 to 1.09 for Kentucky bluegrass cv. 'Enmundi' in 1985. Coefficients of variation for the $1984 \mathrm{KCs}$ ranged from $14.5 \%$ to $18.3 \%$. Somewhat greater variability occurred in 1985, with coefficients of variation ranging from $28.1 \%$ to $29.6 \%$. These values indicate a consistent relationship between ET predicted by the equation and actual ET rates of the five grasses.

When the individual KCs are grouped and analyzed on a biweekly basis (Table 6) , more variation in the Penman methods' predictive ability is revealed. In 1984, there is a general trend for over-prediction 
in July to under-prediction in September. This trend is reversed in the 1985 biweekly analysis. The KCs for all species range from 0.72 to 1.23 . Given the average ET rate of $3.6 \mathrm{~mm} / \mathrm{day}$ found in this study, this variation represents roughly five to ten $\mathrm{mm}$ of water transpired over a two week period, which is negligable in the context of an irrigation scheduling program.

It is concluded that the modified Penman equation method can consistently predict ET rates of the five grasses included in this study, and can be a reliable and effective tool for scheduling irrigation of turf in southern New England.

B. Pan evaporation method:

Seasonal crop coefficients derived by the pan evaporation method (KCpan) in 1984 and 1985 (Table 7) were found to be more variable than those derived by the Penman equation method. Seasonal KCpan means ranged from 0.86 to 1.35 . In 1984, KCpan coefficients of variation ranged from $33.8 \%$ to $37.5 \%$. Greater variability was found in 1985 , as it was with the Penman equation $\mathrm{KCs}$, with coefficients of variation ranging from $41.8 \%$ to $44.6 \%$.

An even greater degree of variation is observed when the KCpan values are analyzed on a biweekly basis. Table 8 contains the biweekly pan crop coefficients 
calculated in 1984. Values range from 0.68 to 1.51 , and no seasonal trend is evident. The pan evaporation method is concluded to be a less consistent means to predict turf water use in southern New England than is the modified Penman equation. 
Table 5. Average seasonal crop coefficients (KCs) for five cool-season turfgrasses based on the Penman equation method in 1984 and 1985.

Species

$\underline{1984}$

$\underline{1985}$

\begin{tabular}{lllllll}
\hline & KC & CV & KC & CV \\
\hline KBb & 1.02 & $a^{*}$ & 15.0 & 0.97 & $\mathrm{~b}$ & 29.6 \\
KBe & 1.01 & a & 15.4 & 1.09 & a & 28.1 \\
PR & 1.01 & a & 15.3 & 1.05 & a & 28.6 \\
RF & 1.00 & a & 14.5 & 0.95 & b & 28.4 \\
HF & 0.88 & b & 18.4 & 1.04 & a & 28.3 \\
\hline
\end{tabular}

* Means followed by the same letetr are not significantly different at the $5 \%$ level based on Duncan's Multiple Range test.

$\mathrm{CV}=$ Coefficient of variation 
Table 6. Aver ge biweekly crop coefficients (KCs) for five cool-season turfgrasses in 1984 and 1985, based on the Penman equation method.

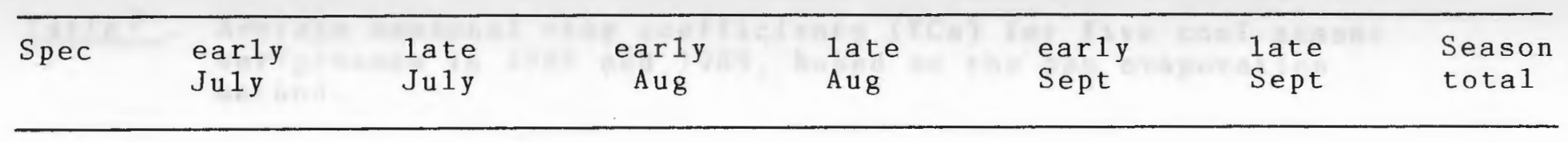

\begin{tabular}{|c|c|c|c|c|c|c|c|c|c|c|}
\hline \multicolumn{11}{|l|}{1984} \\
\hline $\mathrm{KBb}$ & 0.92 & $a^{*}$ & 1.02 & $\mathrm{a}$ & 0.93 a & 0.91 a & $1.23 \mathrm{a}$ & 1.09 & a & 1.02 \\
\hline $\mathrm{KBe}$ & 0.88 & $\mathrm{a}$ & 0.97 & $\mathrm{a}$ & $0.88 \mathrm{a}$ & 0.91 a & $1.21 \mathrm{a}$ & 1.10 & $\mathrm{a}$ & 1.01 \\
\hline $\mathrm{RF}$ & 0.87 & $\mathrm{a}$ & 0.96 & $\mathrm{a}$ & $0.87 \mathrm{a}$ & $0.87 \mathrm{a}$ & $1.18 \mathrm{a}$ & 1.11 & $\mathrm{a}$ & 1.00 \\
\hline PR & 0.89 & a & 0.98 & $a$ & 0.90 a & $0.90 \mathrm{a}$ & $1.20 \mathrm{a}$ & 1.12 & $\mathrm{a}$ & 1.10 \\
\hline $\mathrm{HF}$ & 0.80 & $b$ & 0.82 & $\mathrm{~b}$ & $0.77 \mathrm{~b}$ & $0.72 \mathrm{~b}$ & $1.01 \mathrm{~b}$ & 0.95 & $\mathrm{~b}$ & 0.88 \\
\hline
\end{tabular}

$\begin{array}{llllllllll}\frac{1985}{\mathrm{KBb}} & 1.09 \mathrm{a} & 1.07 \mathrm{~b} & 0.74 \mathrm{c} & 0.78 \mathrm{c} & * * & 0.83 \mathrm{c} & 0.97 \mathrm{~b} \\ \mathrm{KBe} & 1.17 \mathrm{a} & 1.22 \mathrm{a} & 0.89 \mathrm{a} & 0.96 \mathrm{a} & * * & 0.95 \mathrm{a} & 1.09 \mathrm{a} \\ \mathrm{RF} & 1.04 \mathrm{a} & 1.03 \mathrm{~b} & 0.75 \mathrm{c} & 0.84 \mathrm{bc} & * * & 0.84 \mathrm{c} & 0.95 \mathrm{~b} \\ \mathrm{PR} & 1.14 \mathrm{a} & 1.17 \mathrm{a} & 0.83 \mathrm{~b} & 0.90 \mathrm{ab} & * * & 0.87 \mathrm{~b} & 1.05 \mathrm{a} \\ \mathrm{HF} & 1.14 \mathrm{a} & 1.15 \mathrm{a} & 0.83 \mathrm{~b} & 0.87 \mathrm{abc} & * * & 0.89 \mathrm{~b} & 1.04 \mathrm{a}\end{array}$

* Means followed by the same letter are not significantly different from other species means at the $5 \%$ level based on Duncan's Multiple Range test.

* no crop coefficients were computed in early September of 1985 due to equipment failure resulting from Hurricaine Gloria. 
Table 7 . Average seasonal crop coefficients (KCs) for five cool-season turfgrasses in 1984 and 1985 , based on the pan evaporation method.

\begin{tabular}{lllllll}
\hline Species & \multicolumn{3}{c}{1984} & \multicolumn{3}{c}{1985} \\
\cline { 2 - 7 } & \multicolumn{1}{c}{$\mathrm{KC}$} & $\mathrm{CV}$ & & $\mathrm{KC}$ & $\mathrm{CV}$ \\
\hline $\mathrm{KBb}$ & 1.03 & $\mathrm{a} *$ & 35.4 & 1.18 & $\mathrm{~b}$ & 43.4 \\
$\mathrm{KBe}$ & 1.01 & $\mathrm{a}$ & 35.1 & 1.35 & $\mathrm{a}$ & 43.8 \\
$\mathrm{PR}$ & 1.02 & $\mathrm{a}$ & 33.8 & 1.29 & $\mathrm{a}$ & 43.8 \\
$\mathrm{RF}$ & 0.95 & $\mathrm{a}$ & 33.5 & 1.17 & $\mathrm{~b}$ & 41.8 \\
$\mathrm{HF}$ & 0.86 & $\mathrm{~b}$ & 37.5 & 1.28 & $\mathrm{a}$ & 44.6 \\
\hline
\end{tabular}

* Means followed by the same letter are not significantly different at the $5 \%$ level based on Duncan's Multiple Range test. 
Table 8. Average biweek1y crop coefficients (KCpan) for five cool-season turfgrasses in 1984, based on the pan evaporation method.

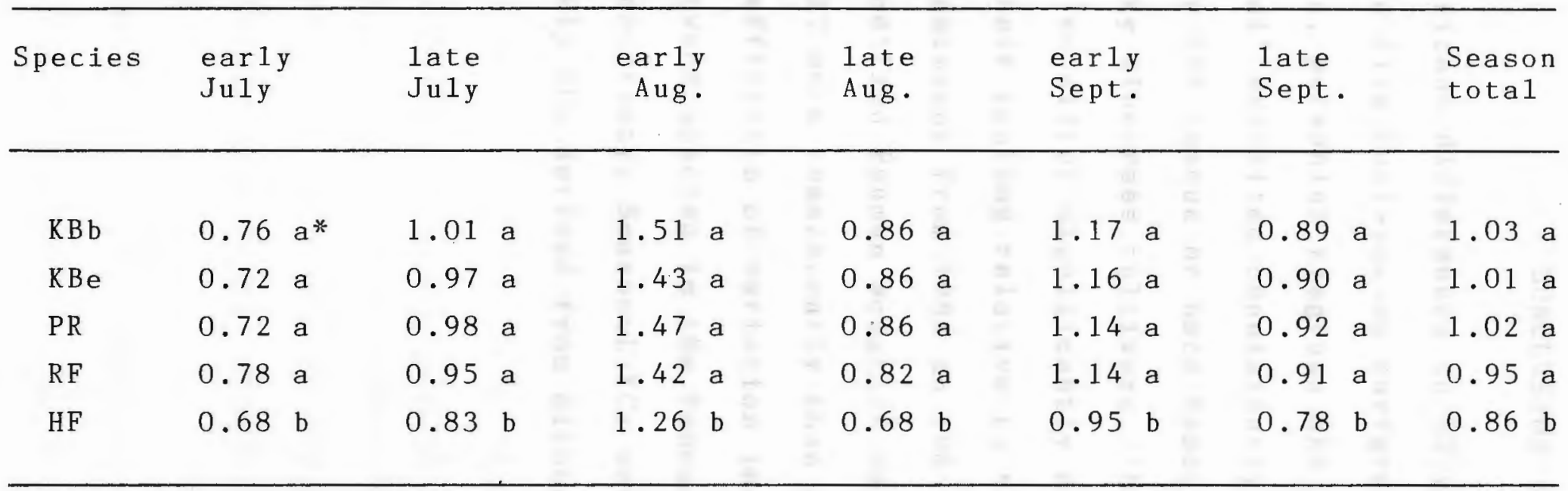

* Means followed by the same letter are not significantly different at the $5 \%$ leve1 based on Duncan's Multiple Range test. 


\section{CONCLUSION}

Significant differences in ET rates were observed between the five cool-season turfgrasses studied. Over two seasons, perennial ryegrass and Kentucky bluegrass cv. 'Enmundi' exhibited consistently higher ET rates than either red fescue or hard fescue. Water use by the two Kentucky bluegrass cultivars, 'Baron' and 'Enmundi', were found to differ significantly during both seasons, although their ranking relative to the other grasses was not consistent from 1984 to 1985.

The modified Penman equation was found to predict turfgrass ET more consistently than the pan evaporation method. Coefficients of variation indicate small differences between species in the Penman equation's predictive consistency. Seasonal $\mathrm{KCs}$ were less variable than biweek1y KCs derived from either method. 
1. Beard, J.B. 1973. Turfgrass: Science and Culture. Prentice-Hall, Inc. Englewood Cliffs, N.J. 658 pp.

2. Beard, J.B. 1986. Turfgrass Water Use Rates. Grounds Maintenance 60-62.

3. Burman, R.D., P.R. Nixon, J.L. Wright and W.O. Pruitt 1980. Water Requirements. In, Design and Operation of Irrigation Systems. Chap 6, M.E. Jensen (ed.) ASAE.

4. Doorenbos, J. and W.O. Pruitt 1977. Guidelines for Predicting Crop Water Requirements. FAO drainage and Irrigation Paper No. 24.

5. Doss, B.D., O.L. Bennett and D.A. Ashley 1964. Moisture Use by Forage Species as Related to Pan Evaporation and Net Radiation. Soil Sci. 98:322-327

6. Doss,B.D., O.L. Bennett, D.A. Ashley and H.A. Weaver 1962. Soil Moisture Regime Effect on Yield and Evapotranspiration from Warm-Season Perennial Forage Species. Agron.J. 54:239-242.

7. Eagleman, J.R. and W.L. Decker 1965. The Role of Soil Moisture in Evapotranspiration. Agron.J. $57: 626-629$.

8. Feldhake, C.M., R.E. Danielson and J.D. Butler 1983. Turfgrass Evapotranspiration I. Factors 
Influencing Rates in Urban Environments. Agron.J. $75: 824-830$.

9. Gardner, W.R. and C.F. Ehlig 1963. The Influence of Soil Water on Transpiration of Plants. J. Geophys. Res. $68: 5719-5724$.

10. Hrehocik, M. 1984. Thirsting for Answers. Part Two. Weeds, Trees and Turf. Aug. 1984.

11. Lemon, E.R., A.H. Glaser and L.E. Satterwhite 1957. Some Aspects of the Relationship of Soil, Plant and Meteorologic Factors to Evapotranspiration. Soil Sci. Am. Proc. 21:464-468.

12. Merva, G. and A. Fernandez 1985. Simplified Application of Penman's Equation for Humid Regions. Soil and Water Div., ASAE Vo1, 28(3).

13. Parlange, J.Y., P.E. Waggoner and G.H. Heichel 1971. Boundary Layer Resistance and Temperature Distribution on Still and Flapping Leaves. Plant Physio1. 48: 437-442.

14. Partridge, N.L. 1941. Comparative Water Useage and Depth of Rooting of Some Species of Grass. Proc. Amer.Soc.Hort.Sci. 48:426-431.

15. Penman, H.L. 1948. Natural Evaporation from Open Water, Bare Soil and Grass. Roy.Soc. London, Proc. Ser.A, 193:120-146. 
16. Peterson, M.P. 1985. Advances in Nebraska Turfgrass Research: Turfgrass Water Use - Part I.

Turfgrass Bul1. Nebraska Turfgrass Foundation, Spring 1985 .

17. Quackenbush, T.H. and J.T. Phelan 1965. Irrigation Water Requirements of Lawns. J.of Irrig. and Drainage Div. ASCE 91(IR2):11-19.

18. SAS Institute Inc.SAS User's Guide: Statistics. Cary, N.C. 1982. pp.584.

19. Shearman, T. and J.B. Beard 1973. Environmental and Cultural Preconditioning Effects on Water Use Rate of Penncross bentgrass. Crop Sci. 13: 424-427.

20. Tovey, R., J. Spencer and S. Muckel 1969.

Turfgrass Evapotranspiration. Agron.J. 61:230-234. 
TURFGRASS RESPONSE

TO DROUGHT STRESS 
ABSTRACT

As the supply of water available for irrigation becomes limited, it is important to identify turfgrasses which can best tolerate deficit moisture conditions, and to establish the critical soil water potential at which those species begin to experience drought stress. The responses of four cool-season turfgrasses to moisture stress were evaluated in two separate studies: the first in a controlled greenhouse environment, and the second under field conditions.

The species studied were: Poa pratensis L. Cv. 'Baron', Lolium perenne L. cv. 'Yorktown II', Festuca rubra var. commutata Gaud. cv. 'Jamestown', and Festuca ovina var. duriuscula L. Koch cv. 'Tournament'. Evapotranspiration (ET) rates were measured using weighing lysimeters containing undisturbed cores of soil and mature turf. Six lysimeters of each species and six well-watered control lysimeters were included in the greenhouse study; four lysimeters of each species and the control group were also used in the field study. Tensiometers and electrical resistance blocks were installed in separate lysimeters to determine the relationship between water loss due to ET and soil water potential. ET rates of all species remained unaffected by decreasing soil water potential until it reached 
-0.6 to -0.8 bars, after which ET rates declined and drought stress symptoms became apparent. The decline in ET rate below a soil moisture potential of -0.6 to -0.8 bars corresponded to a decline in turf quality, growth rate, and relative leaf water content for all species. Leaf water potential decreased by $50-75 \%$ when soil water potential declined to -0.8 bars, but it did not continue to decrease when soil water potential became more negative. Canopy temperature increased slightly when soil water potential reached the stress point of -0.6 bars, but fluctuated thereafter. No consistent increase in canopy temperature was noted until available soil water approached permanent wilting point (approximately -6.0 bars).

Based on the greenhouse study, Kentucky bluegrass and perennial ryegrass showed the most rapid decline in quality and ET rates under moisture stress. Red fescue was intermediate, and hard fescue was the most drought tolerant of the four species.

The range of soil water potential from field capacity to the critical moisture level which occurs between -0.6 and -0.8 bars is the range measured by a tensiometer. This indicates that tensiometers are a useful tool for turfgrass irrigation scheduling. 


\section{INTRODUCTION}

Growing limitations on the supply of water available for irrigation purposes has lead to widespread interest in developing management practices and identifying crop species for maximum water use efficiency. A1though a substantial amount of research is now being devoted to turfgrass water use, 1ittle attention has been directed to the drought response of the cool-season turfgrasses grown in the northeast. However, drought conditions periodically occur during most growing seasons in this region, and as regional differences in turfgrass drought responses due to climate are likely, this information will be useful for turfgrass production and maintenance in southern New England.

Drought tolerance in turfgrass is defined primarily as the ability of the turf to maintain good visual quality while under drought stress. In addition to determining which grasses sustain better quality under drought-stressed conditions, soil water levels and other plant indicators that correlate with the visual onset of drought stress must be identified. This information will aid in the design and utilization of irrigation systems for maximum water use efficiency. 
The objectives of this research were to compare the drought responses of four cool-season turfgrasses, and to identify the soil water potential at which drought stress was initiated. In addition to visual quality ratings, the other plant indicators of drought stress evaluated were growth rate, relative leaf water content, total leaf water potential, and canopy temperature. 


\section{MATERIALS and METHODS}

The response of four turfgrass species to drought stress was investigated in a two-part study; the first in a controlled greenhouse environment during the winter of 1984-1985, and the second in the field during the early summer of 1985 . The species included in the study were: Poa pratensis L. cv. 'Baron', Lolium perenne L. cv. 'Yorktown II', Festuca rubra var. commutata Gaud. cv. 'Jamestown', and Festuca ovina var. duriuscula L. Koch cv. 'Tournament'.

Evapotranspiration (ET) rates were measured using weighing lysimeters as described by Feldhake et a1. with modifications described in Manuscript $I$ of this thesis. The cores of sod and soil were taken from turf swards established in 1980. The soil was an Enfield silt loam (coarse silty over sandy skeletal, mixed, mesic Typic Dystrochrept).

\section{Greenhouse Study}

Six lysimeters of each species and six control lysimeters were arranged in a randomized block design in the greenhouse. The control lysimeters contained Kentucky bluegrass (cv. 'Baron') sod which was kept well-watered through out the experiment, to compare ET rates of the drought stressed grasses with poten- 
tial ET rates when water was not 1 imited.

The grasses were subjected to two successive drought stress periods. The first stress period was continued until the grasses showed visible signs of stress (quality scores below 6.5), after which they were allowed to recuperate under we11-watered conditions for three weeks. The second stress period was continued to permanent wilting point, when plant death occurred. The data from the two tests were combined for analysis.

Supplementa1 1 ighting ( 180 watts $\left./ \mathrm{m}^{2}\right)$ was provided 14 hours per day, using a combination of fluorescent and sodium vapor lamps, to ensure adequate and uniform light distribution. The uniformity of light distribution was measured using a LiCor Radiometer (LI-170 Quantum/ Radiometer/Photometer). Incoming radiation was measured over each lysimeter at night, to ensure a uniform distribution of supplemental lighting alone. Incoming solar radiation was measured over each lysimeter four times over the course of one day to make sure all areas of the greenhouse bench received the same daily solar radiation. Liquid fertilizer $\left(4.8 \mathrm{~g} \mathrm{~N}: 3.7 \mathrm{~g} \mathrm{~K} ; 1.2 \mathrm{~g} \mathrm{P} / \mathrm{m}^{2}\right)$ was applied to each lysimeter eight days before each stress period. Contact fungicides were used as needed to control disease. The temperature in the greenhouse was maintained between $15-24^{\circ} \mathrm{C}$. 
Each lysimeter was weighed at 24 hour intervals to determine water loss due to ET. The balance used ( 0 'Haus $20 \mathrm{~kg}$ solution balance) provided accuracy to the nearest gram (equivalent to $0.02 \mathrm{~mm}$ of water). The six non-stressed lysimeters were irrigated to field capacity every four days.

Quality scores were recorded every three days. Scores range from a perfect score of 9 , representing dense, green, turgid grass cover, to a low of 1 when the grass appears dead. A score of 6.5 or above was considered acceptable turf quality. For the purposes of this study, drought tolerance was defined as the ability of a turfgrass species to maintain acceptable quality while under drought stress.

The grass in each lysimeter was mowed to a height of $5 \mathrm{~cm}$ every three days. The clippings were harvested, and both wet weight and dry weight was measured. Leaf growth rate was monitored on a gram DW clippings/m²/ day basis. The water content of the clippings (gm WW gm $D W$ ) was divided by the water content of the clippings from the same species at full turgor to provide a re1ative leaf water content (RLWC) index.

Leaf water potential of the grasses in the greenhouse experiment was measured using a pressure chamber 
(SoilMoisture Corp. Mode1 3000, with a Mode1 $3015 \mathrm{G} 4$ specimen holder), employing the technique developed by Scholander (11). Apical leaf segments three cm long were excised and immediately sealed into the pressure chamber for measurement. Three leaf samples from each 1ysimeter were measured every three days during the second stress period. Leaf water potential of the wellwatered control grasses was determined at the same time to account for the influence of environmental variation.

\section{Soil Moisture Characteristic Curve}

To establish a soil moisture characteristic curve for this study, six additional lysimeters of perennial ryegrass contained tensiometers installed at a depth of $10 \mathrm{~cm}$. These 1ysimeters contained the same sod and soil used in the drought study lysimeters. The lysimeters were weighed at 24 hour intervals to determine the relationship between change in soil water content (water loss due to ET) and soil water potential down to -0.8 bars. Once -0.8 bars was reached, the 1 ysimeters were irrigated to saturation, and the tensiometers were reset to begin a new dry-down period. This cycle was repeated three times.

Electrical resistance blocks were installed at a depth of $10 \mathrm{~cm}$ in another set of eight lysimeters to 
determine the relationship between change in soil water content and soil water potential between -1.0 and -6.0 bars. The blocks were calibrated prior to placement in the soil using ceramic pressure plate moisture extractors (SoilMoisture Corp., Inc.). These Iysimeters were also weighed at 24 hour intervals, and electrical resistance readings taken at the same time.

All data was subject to an analysis of variance for a randomized block design using a general linear models procedure, SAS Institute, Inc. (10).

Field Drought Stress Study

Four 1ysimeters of each grass species were placed into individual plots $(1.8 \times 2.4 \mathrm{~m})$ of the same species. They were weighed at 24 hour intervals to monitor water loss via ET. Four additional 1ysimeters of each species, maintained in a separate plot area under we1l-watered conditions were also weighed at 24 hour intervals to determine non-stressed, or potential ET.

Rain shelters were placed over the plots every night and during rain events. The rain shelters consisted of $2.1 \times 2.7 \mathrm{~m}$ wooden frames covered with $6 \mathrm{ml}$ polyehtylene sheeting. The legs were $20 \mathrm{~cm}$ high on the south side, and $40 \mathrm{~cm}$ high on the north side, creating 
a $9 \%$ slope to facilitate water runoff away from the plots. The shelters were secured in place by ropes attached to tent stakes embedded in the ground.

0ther than lateral sub-surface water movement from adjacent plots, the turfgrass in the plots surrounding the lysimeters experienced comparable drought stress conditions, thereby avoiding advective influences.

The canopy temperature (Tc) of the grass in the field lysimeters was measured using an Infrared Pyrometer (Omegascope Mode1 OS-2000A). Leaf temperature of the grass in the lysimeters was measured from a distance of one meter every day at approximately 1400 hours. Canopy temperature of the grass in the wellwatered lysimeters was measured at the same time. The difference in Tc between the stressed and non-stressed grasses was calculated daily and plotted against soil water potential to determine the relationship between canopy temperature and water stress in turfgrass. 


\section{RESULTS and DISCUSSION}

Evapotranspiration rate:

Changes in the ET rates of the four turfgrasses in the greenhouse drought stress test followed a similar trend (Figure 1). ET rates remained unaffected by declining soil water potential until a critical moisture level was reached, which occurred between -0.6 and -0.8 bars. Below this point, ET rates declined and drought stress symptoms, namely leaf rolling and changes in leaf color, became apparent. This trend is similar to the model proposed by Gardner et a1. (7), which held that transpiration is governed mainly by meteorologic factors when soil water is available, but beyond a critical soil moisture level, ET rates decline linearly with the remaining available water.

The range of soil water potential from field capacity to the critical moisture level which occurs between -0.6 and -0.8 bars is the range measured by a tensiometer. This indicates that tensiometers are a useful tool for turfgrass irrigation scheduling.

Under non-stressed conditions, above -0.6 bars, hard fescue transpired less rapidly than the other three grasses. This is consistent with previous research into comparative water use rates of cool-season 
grasses under we11-watered conditions $(1,2,8,9)$. Below -0.6 bars, when the grasses were experiencing drought stress, hard fescue sustained the highest transpiration rate of the four grasses. Red fescue was intermediate, and Kentucky bluegrass and perennial ryegrass were least able to sustain potential transpiration rates under drought stressed conditions.

These findings are consistent with Beard's catagorization of drought resistance in cool-season turfgrasses. He rated hard fescue and red fescue "good", Kentucky bluegrass "medium", and perennial ryegrass "fair" in overal1 resistance to drought stress (1). The same trend was evident when quality scores were analyzed (Figure 2). The visual qualtiy of all the grasses declined when soil water potential fell below -0.6 bars. Lowered quality scores have previously been reported for cool-season grasses exposed to drought stressed conditions (6) although no threshold soil water potential was correlated with this decline.

Turf quality and C1ipping growth:

Neither Kentucky bluegrass nor perennial ryegrass sustained acceptable turf quality (a score of 6.5 or above) under moisture stress. Red fescue again ranked intermediate, and hard fescue maintained acceptable 
Figure 1. Evapotranspiration rates (ETa/ETwW) of four coolseason turfgrasses undergoing drought stress.

(Greenhouse study)

$(\mathrm{ETa}=\mathrm{ET}$ of stressed grasses, $\mathrm{ETwW}=\mathrm{ET}$ of we11-watered control grasses). 


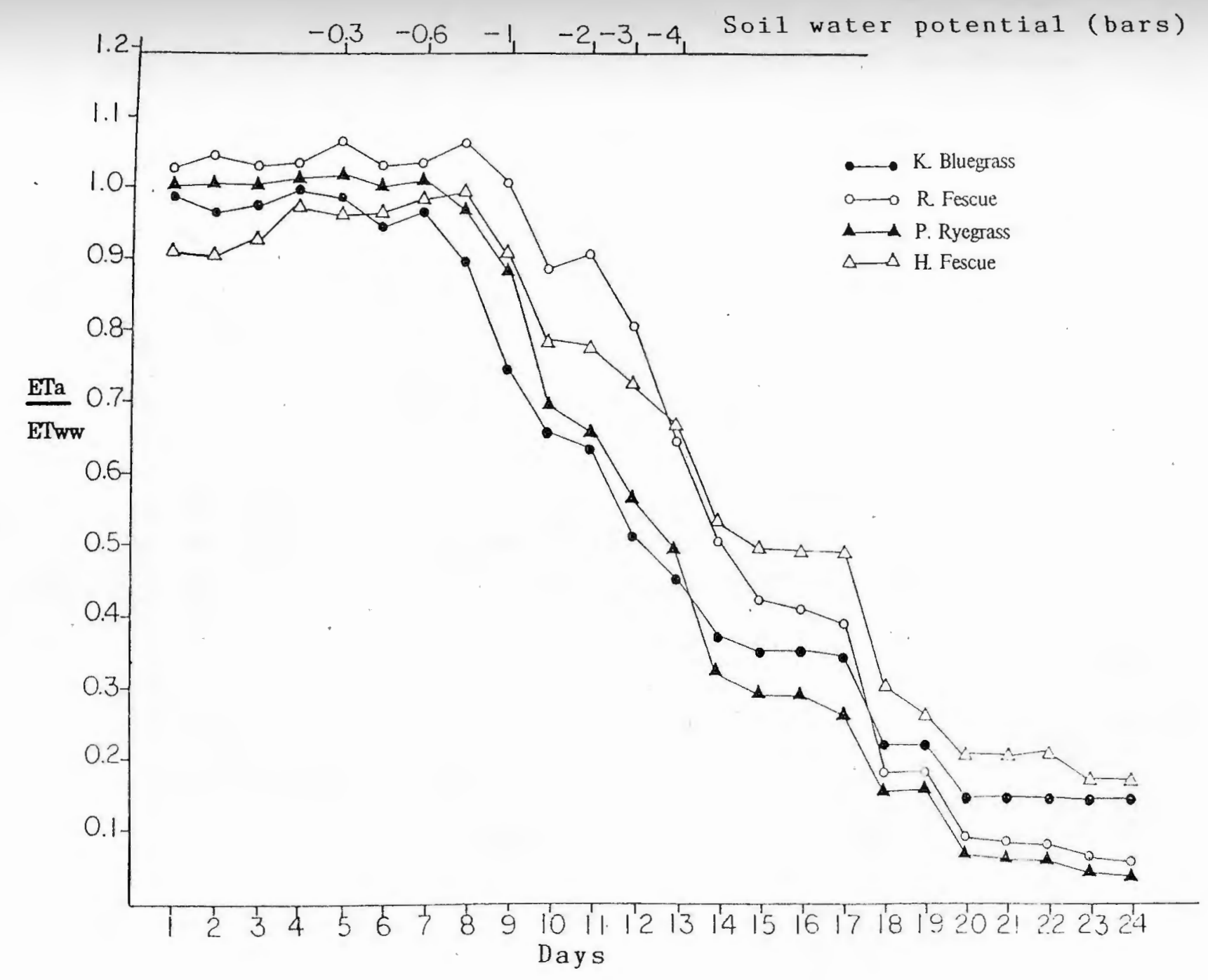


Figure 2. Quality ratings of four cool-season turfgrasses subject to dec1ining soil water potential. (Greenhouse study). 


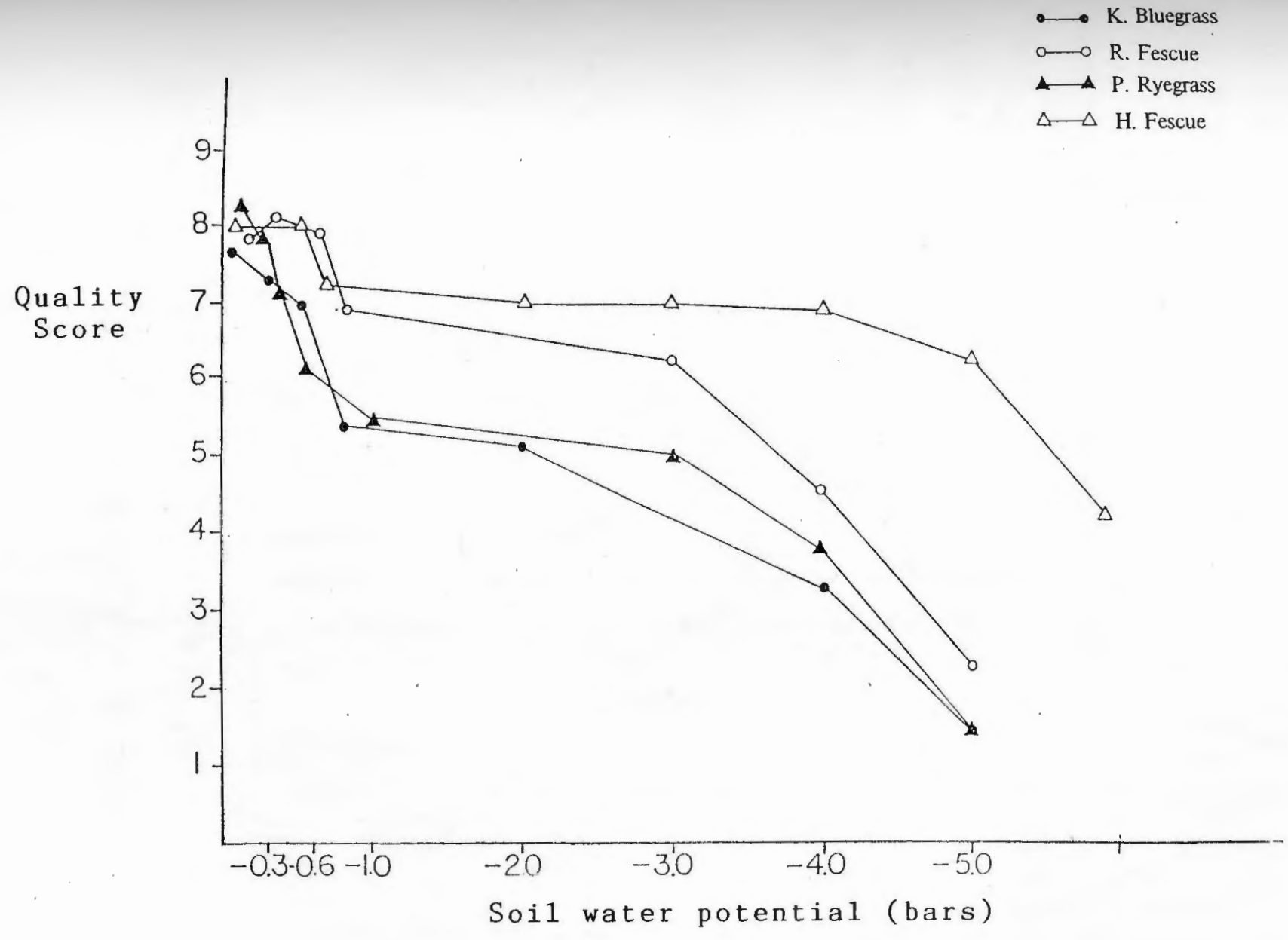


Figure 3. Leaf growth rate of four cool-season turfgrasses subject to declining soil water potential. (Greenhouse study). 


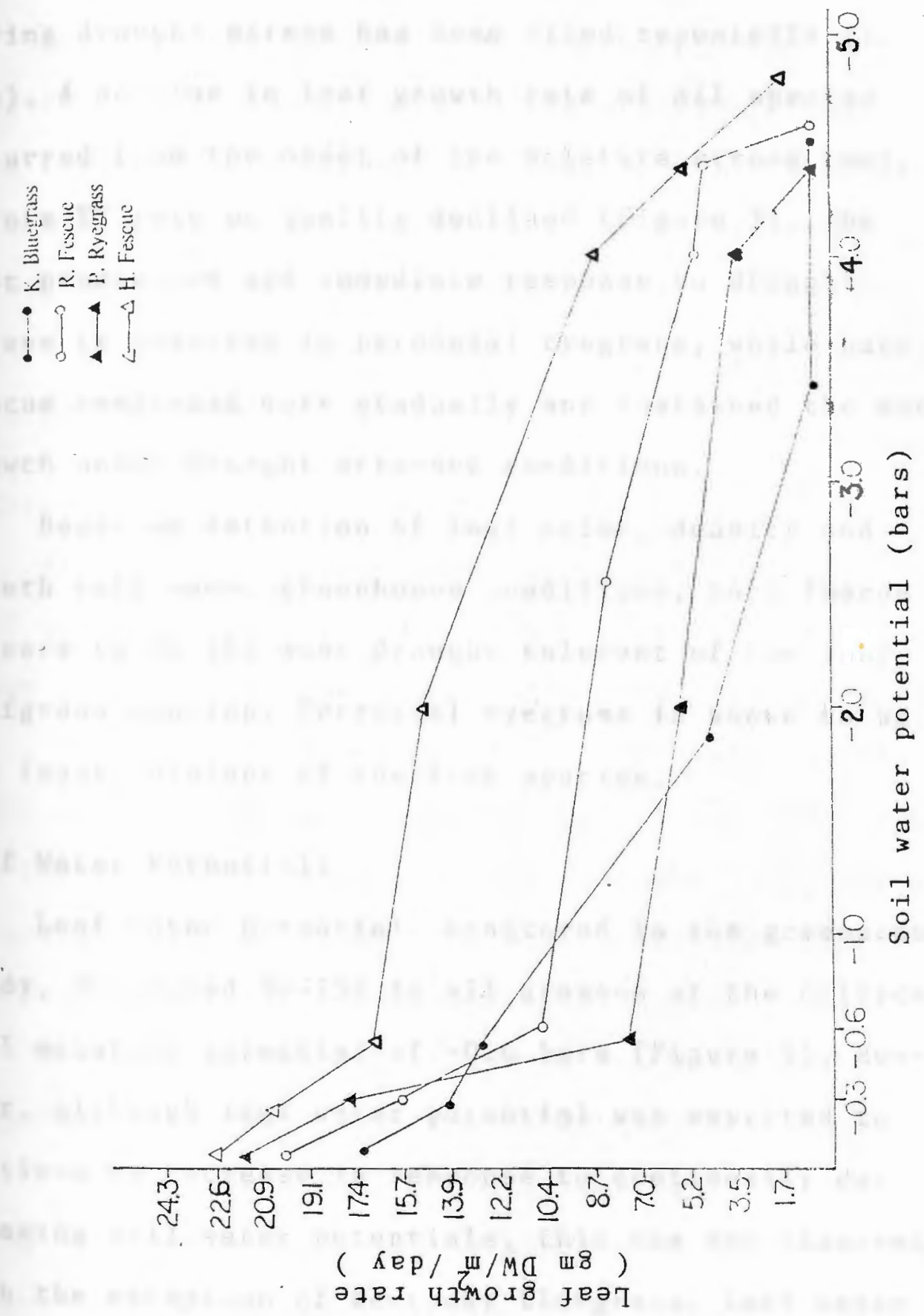


turf quality almost to permanent wilting point (approximate1y -6.0 bars).

Reduced growth rate of turfgrass leaf tissue during drought stress has been cited repeatedly ( 1 , 4,6). A decline in leaf growth rate of all species occurred from the onset of the moisture stress test, before ET rate or quality declined (Figure 3). The most pronounced and immediate response to drought stress is observed in perennial ryegrass, while hard fescue responded more gradually and sustained the most growth under drought stressed conditions.

Based on retention of leaf color, density and growth rate under greenhouse conditions, hard fescue appears to be the most drought tolerant of the four turfgrass species. Perennial ryegrass is shown to be the least tolerant of the four species.

Leaf Water Potential:

Leaf water potential, monitored in the greenhouse study, decreased $50-75 \%$ in all grasses at the critical soil moisture potential of -0.6 bars (Figure 4 ). However, although leaf water potential was expected to continue to decrease in response to continually decreasing soil water potentials, this was not observed, with the exception of Kentucky bluegrass. Leaf water 
potentials were sustained roughly at the plateau achieved when the soil water potential was -0.6 bars, while soil water potential continued to decline.

The data are difficult to interpret because of the difficulties inherant in using the pressure chamber with fine-leaved grasses. The time required to take an adequate number of samples and the subjectivity involved in visually discerning the relatively minute quantities of cell sap expressed from each sample introduce considerable variability in the data.

Relative Leaf Water Content:

As with other parameters investigated, the relative leaf water content (RLWC) of al1 four grasses declined under stress conditions, when soil water potential fell below -0.6 bars (Figure 5 ). Hard fescue retained the greatest amount of water in its leaf tissue under stress, red fescue was intermediate, and Kentucky bluegrass and perennial ryegrass showed the most pronounced decline in RLWC under drought stressed conditions.

These values represent the water content of the clippings, which by definition must be at least partially turgid since no flaccid tissue was harvested using our system. RLWC is therefore considered to be a partial index of leaf turgidity, a1though clipping yields must also be taken into account. 
Figure 4. Total leaf water potential of four cool-season turfgrasses subject to declining soil water potential. (Greenhouse study).

$\left(\psi_{\text {LS }}=1\right.$ leaf water potential of stressed grasses, $\psi_{L W}=1$ leaf water potential of non-stressed control grasses). 


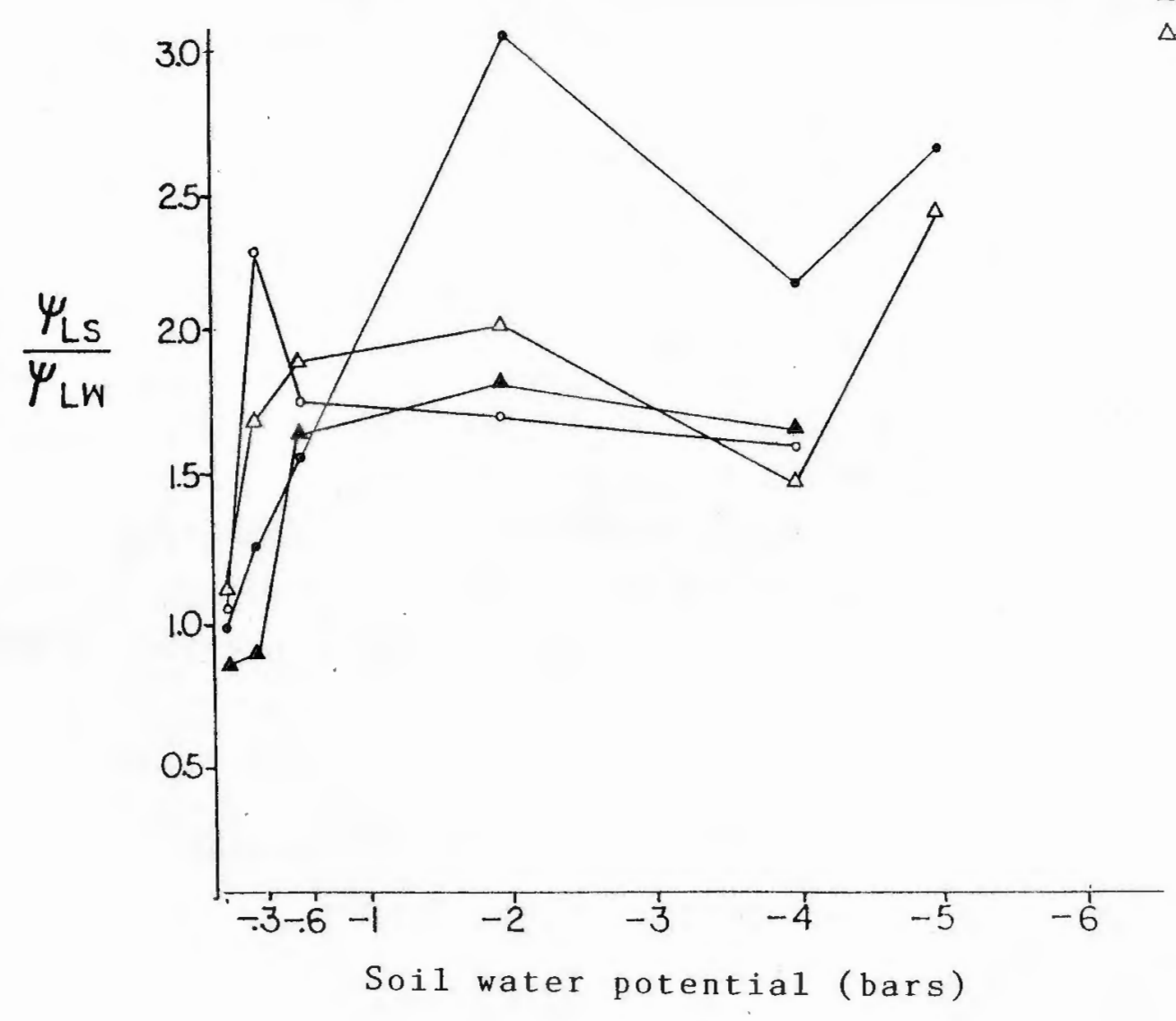

- K. Bluegrass

$\Longrightarrow$ R. Fescue

A D. P. Ryegrass

$\triangle \triangle$ H. Fescue 
Figure 5. Relative leaf water content of four cool-season turfgrasses subject to declining soil water potentials. (Greenhouse study).

$\left(\mathrm{H}_{2} \mathrm{O}_{\mathrm{S}}=\mathrm{RLWC}\right.$ of stressed grasses, $\mathrm{H}_{2} \mathrm{O}_{\mathrm{W}}=\mathrm{RLWC}$ of non-stressed control grasses). 


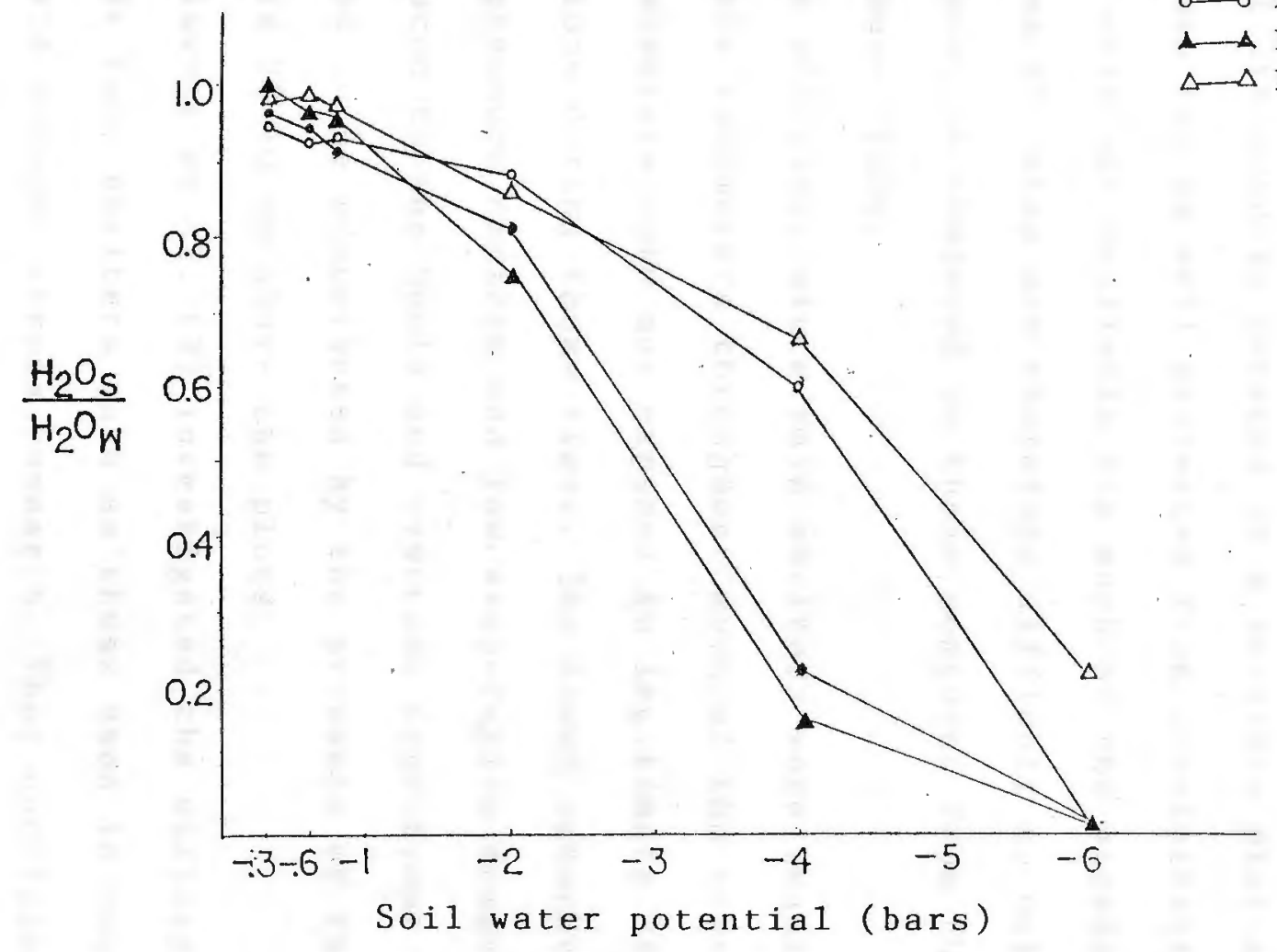


Field Drought Stress Test

The 1985 field drought stress test was conducted in late June - early July, during a period of frequent rainfall events. This presents numerous difficulties in interpreting the results. Data from the well-watered control lysimeters, located in a separate plot area which was not as well protected from precipitation events were not available for much of the stress period. Relative ET rates are therefore difficult to calculate and cannot be compared to those computed from the greenhouse study.

In addition, since rain shelters were required to cover the lysimeters throughout much of the experiment, the Iysimeters were not exposed to legitimate "field" conditions during those times. The lower saturation vapor pressure deficit and low evaporative demand introduced by the humid and overcast conditions is expected to be exacerbated by the presence of the rain shelters $20-40 \mathrm{~cm}$ above the plots.

Clawson et al. (3) investigated the utility of portable rain shelters such as those used in this study for field drought stress research. They concluded that the shelters adversely affected the microclimate by reducing net radiation by 40 percent. They also recorded an increase in leaf temperature of about $8^{\circ} \mathrm{C}$ 
when the shelters were in place.

As a result of these complications, the data from the field drought stress experiment cannot be considered conclusive. Canopy temperature measurements are the only data from the field study included in the analysis of the results.

Canopy temperature:

Canopy temperature (TC) increased by roughy $4^{\circ} \mathrm{C}$ at -0.6 bars soil water potential (Figure 6). Substantial temperature fluctuation was observed as soil water potential continued to decline. Consistent increases in Tc were not recorded until the grasses approached permanent wilting point. This suggests that Tc measurements are an inadequate means of determining the water status of turfgrass, since the grasses will have already been severely drought stressed by the time consistent temperature increases are detected by this method. 
Figure 6. Canopy temperature of four cool-season turfgrasses subject to declining soil water potential. (Field study)

( $\Delta \mathrm{C}^{\circ}$ is the difference in temperature between stressed and non-stressed grasses). 


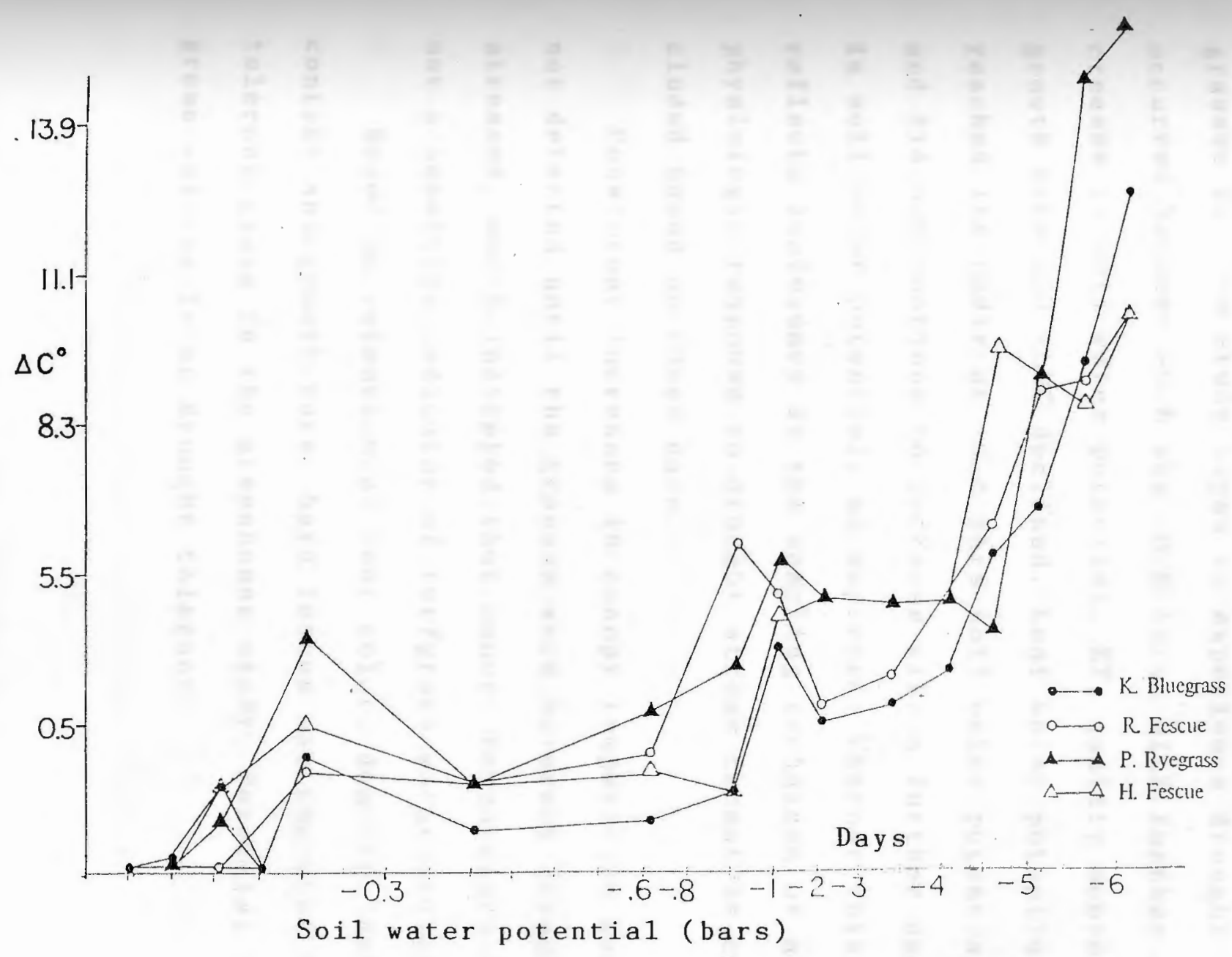

G 


\section{CONCLUSION}

The critical soil water potential below which the grasses in this study began to experience drought stress occurred between -0.6 ans -0.8 bars. With further decreases in soil water potential, ET, quality scores, growth rate and RLWC declined. Leaf water potential reached its nadir at -0.6 bars soil water potential, and did not continue to decrease with a further decline in soil water potential, as expected. Whether this reflects inadequacy in the sampling technique or a true physiologic response to drought stress cannot be concluded based on these data.

Consistent increases in canopy temperature were not detected until the grasses were severely drought stressed, which indicated that canopy temperature is not a sensitive indicator of turfgrass water status.

Based on retention of leaf color, density, water content and growth rate, hard fescue was the most drought tolerant grass in the greenhouse study. Perennial ryegrass was the least drought tolerant. 


\section{LITERATURE CITED}

1. Beard, J.B. 1973. Turfgrass; Science and Culture. Prentice-Hall Inc. Englewood cliffs, N.J. 658 pp.

2. Beard, J.B. 1986. Turfgrass Water Use Rates.

Grounds Maintenance 60-62.

3. C1awson, K.L., B.L. B1ad and J.E. Specht 1986.

Use of Portable Rainout Shelters to Induce Water

Stress. Agron.J. 78:120-123.

4. Doss, B.D., O.L. Bennett, D.A. Ashley and H.A.

Weaver 1962. Soil Moisture Regime Effect on Yield and Evapotranspiration from Warm-Season Perennia1

Forage Species. Agron.J. 54:239-242.

5. Feldhake, C.M., R.E. Danielson and J.D. Butler

1983. Turfgrass Evapotranspiration I. Factors

Influencing Rate in Urban Environments. Agron.J. $75: 824-830$.

6. Feldhake, C.M., R.E. Danielson and J.D. Butler 1984. Turfgrass Evapotranspiration II. Responses to Deficit Irrigation. Agron.J. 76:85-89.

7. Gardner, W.R. and C.F. Ehlig 1963. The Influence of Soil Water on Trnaspiration of Plants. J.Geophys.Res. 68:5719-5724.

8. Partridge, N.L. 1941. Comparative Water Useage and Depth of Rooting of Some Species of Grass. Proc.Amer.Soc.Hort.Sci. 48:426-431. 
9. Peterson, M.P. 1985. Advances in Nebraska Turfgrass Research: Turfgrass Water Use - Part I. Turfgrass Bu11. Nebraska Turfgrass Foundation, Spring 1985.

10. SAS Institute Inc. 1982. SAS User's Guide: Statistics. Cary, N.C. 584 pp.

11. Scholander, P.F., H.T. Hamme1, E.A. Hemmingsen and E.D. Bradstreet 1964. Hydrostatic Pressure and Osmotic Potential in Leaves of Mangroves and Some Other Plants. Proc.N.A.S. Vol.52:119-125. 


\section{Appendix I}

\section{LITERATURE REVIEW}

A) We11-watered study:

Models developed to predict turf evapotranspiration (ET) have estimated that it takes between 10-20 inches (rough1y $25-50 \mathrm{~cm}$ ) of irrigation water per year to maintain we11-watered conditions for turf in Rhode Island (36). Seasonal water use for a 45 ha golf course ranges from 51 to 102 million liters of water, which is the equivalent to the water consumption needs of a town with a population of 925-1850 (37).

Although runoff and deep drainage can contribute to water loss, transpiration accounts for most of the water lost from a dense turfgrass canopy (1). It has previously been established that transpiration rate varies between turfgrass species $(1,2,13,32,34)$, and in some cases even between cultivars within a species. In 1941, N.L. Partridge demonstrated substantial differences in ET rates between ten grass species under we11watered conditions, although no statistical analysis of the data was indicated (32). Of the cool-season grasses common to both his study and the present research, Kentucky bluegrass was found to use consistently more water than the fescues. 
Peterson (34) evaluated ET rates of seven coolseason turfgrasses grown under well-watered conditions in Nebraska. Kentucky bluegrass was found to use the most water $(0.83 \mathrm{~cm} / \mathrm{day})$, followed by chewings fescue, hard fescue, and perennial ryegrass $(0.81,0.79$ and $0.69 \mathrm{~cm} / \mathrm{day}$, respectively). These measurements were obtained under conditions of high evaporative demand which exist in semi-arid regions, and represent roughly twice the transpiration rates recorded in the northeastern U.S.

Beard (2) ranked potential ET (PET) rates (the maximum that occurs under non-1imiting soil moisture conditions) of some major turfgrasses. Hard fescue and chewings fescue were ranked intermediate $(0.7-0.85 \mathrm{~cm} /$ day), perennial ryegrass ranked high $(0.85-1.0 \mathrm{~cm} / \mathrm{day})$, and Kentucky bluegrass ranked very high (>1.0 cm/day). This study was performed in a growth chamber under constant environmental conditions.

Several morphological characteristics have been reported to contribute to turf water use. Of these, increased canopy density has been shown to reduce ET by increasing the boundary layer resistance to convective air flow within the canopy $(24,31)$. This increased resistance results in a reduced saturation vapor deficit surrounding the plants in the turf stand, 
thereby reducing the evaporative demand which drives ET.

Feldhake (16) found Kentucky bluegrass to use 24 percent more water than bermudagrass. This difference is due primarily to the well-documented differences in water use between warm- and cool-season grasses (3,25, 27). However, Feldhake reported that the large difference in canopy density may have contributed to the differences in ET. Kentucky bluegrass has a relatively open canopy subject to convective air flow, while bermudagrass grows in a dense, closed mat.

In a study of the ET rates of eleven warm-season turfgrasses, Beard (21) noted a higher ET rate when leaves were erect, shoot density was 1 ow and there was a large leaf area. Similarly, Biran et a1. (3) observed a high negative correlation between stand density and water consumption in $\mathrm{C}-4$ grasses $(\mathrm{r}=-0.85, \mathrm{P}<0.05)$.

Although morphologic characteristics have been shown to influence turf water use, environmental factors external to the plant are the primary determinants of ET rates when soil water is readily available $(12,18)$. Solar radiation, relative humidity, temperature and wind speed are the most important climatic variables influencing ET. Under well-watered conditions, ET 
increases with net radiation $(1,16)$, with temperature (1), with increases in wind speed $(7,8,16,24)$ and with increased saturation vapor pressure deficit (22).

Doorenbos and Pruitt published guidelines to calculate water requirements of crops under different climatic conditions. They used four predictive methods: Blaney-Criddle, Radiation, Penman and pan evaporation. These methods were modified to calculate reference crop ET (ETo) using mean daily climatic data for 10or 30- day periods. Use of the modified Penman method produced the least possible error of plus or minus ten percent in the summer, and up to twenty percent under condition of low evaporative demand. The pan method ranked second in accuracy, with a maximum possible error of fifteen percent depending on the location of the pan. Calculation procedures for the different methods are outlined in FAO publication No.24 (11).

It is noted in the guidelines that these methods are often employed under climatic conditions very different for which they were originally developed, which may limit their applicability. Tanner (45), in a review of ET measurement techniques, recommends the use of weighing lysimeters as an independent check on the suitability of micrometeorological methods, and as a way to calibrate empirical formulas used for 
estimating ET.

Tovey et al. (47) compared actual ET from a mix of cool-season grasses to ET predicted by the pan evaporation, net radiation, and the 0livier and Penman methods. They found that, in genera1, ET estimates are somewhat higher than actual ET measured on a weekly basis. They conclude, however, that a11 of these methods provide comparative1y adequate estimates of lawngrass ET on a weekly, monthly or seasonal basis ( $t$ test significant $1 \%$ leve1).

Pruitt and Angus (38) found the daily ETp (mm/day) from irrigated perennial ryegrass to be related to Class A pan evaporation by the equation ETp $=0.67 \mathrm{E}$ pan + 0.45 ( $r=0.94)$ from January through May, and to be $\mathrm{ET}_{\mathrm{p}}=0.77 \mathrm{E}$ pan $+0.03(\mathrm{r}=0.90)$ for Ju1y through September. No estimate of error for the daily values was given, although the scatter was large. Correlation coefficients and coefficients of variation indicate that the consistency of the pan estimates increases with longer period averages.

Climatic variability, particularly in humid regions, requires a relatively long time period to make reasonably accurate estimates using the pan method (45). The ca1ibration of the pan to a given site is also mandatory (11). The pan evaporation method has a tendancy to 1 ag climatic conditions due to the high specific heat of water. 
B) Drought Stress study:

When soil moisture is readily available, transpiration rates are governed primarily by meteorological factors $(12,18)$. Methods have been developed to predict the potential transpiration rates of crops under wellwatered conditions ( 11 ). However, when soil water supply is limited, plant water use depends mainly on plant characteristics and the available water in the $\operatorname{soi1}(9,12,47)$.

Stanhill (44) reviewed the extensive literature addressing the question whether soil water between field capacity and permanent wilting point is equally available to plants for growth. Of the 80 papers reviewed, the results of 66 showed that plant growth did respond to differences in soil moisture content.

The relationship between soil water content and plant water use has been presented in a variety of models, in an attempt to determine the soil moisture content at which the actual transpiration rate falls below the potential rate, and whether this can be predicted for any soil-plant-weather combination. 
Water moves through the soil to plant roots and through the plant to the transpiring leaves along a gradient of negative pressure (water potentia1). Gardner (19) presents an equation for the flow of water from the soil to the roots of a transpiring plant. He concluded that the water potential gradient between soil and root needed to maintain a given transpiration rate is proportional to the rate of water uptake or the potential transpiration rate, and inversely proportional to the capillary conductivity of the soil.

As the soil dries, large suction (negative pressure) gradients develop between the root and the soil. To maintain transpiration in a drying soil where capi11 ary conductivity is rapidly decreasing and the water potential of the root is decreasing correspondingly, the water potential of the leaves must decline even further to maintain the necessary suction gradient. Decreased leaf water potential coincides with decreased turgor pressure, which leads to stomatal closure. This reduces the permeability of the leaf surface to water flow and hence reduces transpiration rate.

The soil moisture content at which transpiration rates are reduced depends on a variety of interactive factors. Morphological and physiological attributes of the plant (rooting depth, stomatal density, etc.) play 
a major role. Meteorologic conditions also have an influence. Increased evaporative demand will cause leaf water potential to decline more rapidly, leading to a more rapid decline in turgor and transpiration rate (20). Soil properties which influence the relationship between soil moisture content and soil water potential determine the the quantity of water "available" to the plant. Numerous models have been proposed to describe the relationship between soil moisture and ET rates. Veihmeyer and Hendrickson (50) proposed that ET rates remain unaffected by decreasing soil moisture until the level of soil moisture approaches the wilting point, at which time ET rate falls rapidly. Thornthwaite (46) stated that ET rates will be half the maximum for the prevailing meteorolgic conditions at a soil moisture content of half the available water. Other models postulate that ET declines linearly with a decrease in soil water from field capacity to permanent wilting point (20). Still others, such as Pierce (35) proposed a logarithmic relationship between soil water and ET. The limitations, and hence incompatibility, of these models rest largely on their omission of var- 
iabilty in soil properties and climatic conditions. The former contributes significantly to soil water availability to plants, and the latter directly influences plant response to soil water, or potential water use rate by the plant.

Denmead and Shaw (9) found the relationship between ET and soil moisture varied with the evaporative demand imposed by the environment. It was shown that the model proposed by Veihmeyer applied to conditions of low evaporative demand, while the Thornthwaite model applied to conditions of high evaporative demand. The logarithmic relationship proposed by Pierce was shown to correspond to averaeg or variable evaporative demand conditions.

Eagleman and Decker (14) evaluated the magnitude of decreasing ET rates of soybeans relative to decreasing soil water potential. They concluded that the influence of variations in evaporative demand on ET rates can be eliminated through the use of the ratio between measured ET and potential ET computed from meteorologic data using the modified Penman equation.

Rather than identifying a threshold level in soil water potential below which drought stress occurs, numerous studies have concentrated on plant indicators of stress under deficit moisture regimes. These in- 
clude visual indications (wilting, leaf rolling, changes in leaf color), changes in leaf water content or turgor potential, total leaf water potential, and canopy temperature.

The first visible sign of drought stress in turfgrass is wilting. Wilt is defined as a "visible drooping, rolling, or folding of turfgrass leaves resulting from loss of turgidity" (1). Turfgrass species differ in wilting tendancy. Fescues have a very low to low wilting tendancy, while Kentucky bluegrass and perennial ryegrass are ranked intermediate in wilting tendancy (1).

Wilting is caused by a decrease in leaf turgor associated with a reduction in leaf water content. This occurs under drought stress conditions when transpiration rate exceeds the rate of soil water extraction by the roots. Relative leaf water content (RLWC) is the water content (on a percent basis) of leaf tissue relative to the water content of the tissue when turgid. This measurement has been positively correlated to leaf water potential, and has been used as a plant water status index $(15,22,30)$.

A change in, leaf color, ranging from grey to bluegreen, frequently accompanies wilting. This color change will lower the visual quality rating of turf- 
grasses. A limited degree of water stress has been shown to have no adverse effect on turfgrass quality $(10,29)$. Feldhake et a1. (17), in a study involving Kentucky bluegrass, found that an irrigation deficit of $27 \%$ will only decrease growth, whereas larger deficits cause quality to decline rapidly. A reduction in turfgrass growth resulting from drought stress has been reported $(1,13)$.

Total leaf water potential has gained wide recognition as a measure of plant water status. Total leaf water potential results from the combined but opposite actions of pressure (turgor) potential ( $\psi_{\mathrm{p}}$ ) and osmotic potential $\left(\psi_{\pi}\right)$. The relationship between these components as volume changes is schematically described in the so-called Höfler diagram (40). The pressure bomb technique developed by Scholander (42) is regarded as an accurate method for estimating leaf water potential $(4,30,48)$. The $1 \mathrm{ack}$ of references to this method in turfgrass 1iterature reflects the difficulty in adapting the technique to fine-leaves grass species.

The temperature of a turfgrass canopy is expected to increase during periods of drought stress, due to the loss of transpirational cooling. Measurement of canopy temperature as a plant water status indicator 
has been investigated for irrigation scheduling purposes. Biran et a1. (3) compared stressed and nonstressed leaf temperature of two $\mathrm{C}-3$ and nine $\mathrm{C}-4$ grasses. They found leaf temperature differences in the stressed and non-stressed $C-3$ grasses to be almost $5^{\circ} \mathrm{C}$, and almost $8^{\circ} \mathrm{C}$ differences between stressed and non-stressed C -4 grasses. Feldhake et a1. (17) found that turfgrass canopy temperature increases $1.7^{\circ} \mathrm{C}$ for each ten percent decrease in irrigation regime up to a $70 \%$ decrease. 


\section{BIBLIOGRAPHY}

1. Beard, J.B. 1973. Turfgrass: Science and Cu1ture. Prentice-Hall Inc. Englewood Cliffs N.J. 658 pp.

2. Beard, J.B. 1986. Turfgrass Water Use Rates. Grounds Maintenance 60-62.

3. Biran, I.B., I. Bravdo, E. Bushkin-Harav and E. Rawitz 1981. Water Consumption and Growth Rate of Eleven Turfgrasses as Affected by Mowing Height, Irrigation Frequency and Soil Moisture. Agron.J. $73: 85-89$.

4. Boyer, J.S. 1969. Measurement of the Water Status of Plants. Ann.Rev.P1ant Physio1. 20:351-364.

5. Burman, R.D., P.R. Nixon, J.L. Wright and W.O. Pruitt 1980. Water Requirements. In Design and Operation of Irrigation Systems. Chap 6, M.E. Jensen (ed.) ASAE.

6. Clawson, K.L., B.L. Blad and J.E. Specht 1986. Use of Portable Rainout Shelters to Induce Water Stress. Agron.J. 78:120-123.

7. Danielson, R.E., W.E. Hart, C.M. Fe1dhake and P.M. Haw 1979. Water Requirements for Urban Lawns. Colo. completion report OWRT Proj.B-035-WYO 91 p. 8. Davenport, D.C. 1965. Versatility of a Small Grass Transpirometer. Univ.of Nottingham School of Agric. Rep. p.54-60. 
9. Denmead, O.T. and R.H. Shaw 1962. Availability of Soil Water to Plants as Affected by Soil Moisture Content and Meteorological Conditions. Agron.J. $54: 385-390$.

10. Dernoeden, P.H. and J.D. Butler 1978. Drought Resistance of Kentucky bluegrass cultivars. Hort. Science 13 (6):667-668.

11. Doorenbos, J. and W.0. Pruitt 1977. Guidelines for Predicting Crop Water Requirements. FAO Drainage and Irrigation paper No.24.

12. Doss, B.D., O.L. Bennett and D.A. Ashley 1964. Moisture Use by Forage Species as Related to Pan Evaporation and Net Radiation. Soil Sci.98:322-327.

13. Doss, B.D., O.L. Bennett, D.A. Ashley and H.A. Weaver 1962. Soil Moisture Regime Effect on Yield and Evapotranspiration from Warm-Season Perennial Forage Species. Agron.J. 54:239-242.

14. Eagleman, J.R. and W.L. Decker 1965. The Role of Soil Moisturein Evapotranspiration. Agron.J. $57: 626-629$.

15. Ehrler, W.L. and F.S. Nakayama 1984. Water Stress Status in Guayule as Measured by Relative Leaf Water Content. Crop Sci. 24:61-68.

16. Feldhake, C.M., R.E. Danielson and J.D. Butler 1983. Turfgrass Evapotranspiration I. Factors Influencing Rate in Urban Environments. Agron.J. 75:824-830. 
17. Feldhake, C.M., R.E. Danielson and J.D. Butler 1984. Turfgrass Evapotranspiration II. Responses to Deficit Irrigation. Agron.J. 76:85-89.

18. Gardner, W.R. and C.F. Ehlig 1963. The Influence of Soil Water on Transpiration of Plants. J. Geophys.Res. 68:5719-5724.

19. Gardner, W.R. 1960. Dynamics of Water Availability to Plants. Soil Sci. $89: 63-73$.

20. Hillel1, D. 1982. Introduction to Soil Physics. Academic Press Inc, London.

21. Hrehocik, M. 1984. Thirsting for Answers. Part Two. Weeds, Trees and Turf. Aug.1984.

22. Hsaio, T.C. 1973. Plant Responses to Water Stress. Ann.Rev.P1ant Physiol. 24:519-570.

23. Hsaio, T.C. and E. Acevedo 1970. Plant Responses to Water Deficits, Water Use Efficiency and Drought Resistance. Agric.Meteorol. 14:59-84.

24. Johns, D., J.B. Beard and C.H.M. van Bave1 1983. Resistances to Evapotranspiration from a St. Augustine Turf Canopy. Agron.J. 75:419-422.

25. Kneebone, W.R. and I.L. Pepper 1982. Consumption Water Use by Sub-irrigated Turfgrasses under Desert Conditions. Agron.J. 74:419-423. 
26. Lemon, E.R., A.H. Glaser and L.E. Satterwhite 1957. Some Aspects of the Relationship of Soil, P1ant and Meteorologic Factors to Evapotranspiration. Soil Sci.Am.Proc. 21:464-468.

27. Marsh, A.W., R.A. Strohman, S. Spaulding, V. Younger and V. Gibeault 1980. Determining the Water Requirements of Various Turfgrass Species. Irrig.Assoc.Ann. Tech.Conf.Proc. 1:34-45.

28. Merva, G. and A. Fernandez 1985. Simplified Application of Penman's Equation for Humid Regions. Soil and Water Div. ASAE Vo1.28(3)

29. O'Neil, T. and R.N. Carrow 1982. Kentucky bluegrass Growth and Water Use Under Different Soil Compaction and Irrigation Regimes. Agron.J. 74:933-936. 30. O'Toole, J.C., N.C. Turner, O.P. Namuco, M. Dingkukn and K.A. Gomez 1984. Comparisons of Some Crop Water Stress Measurement Methods. Crop Sci. $24: 1121-1128$.

31. Parlange, J.Y., P.E. Waggoner and G.H. Heiche1 1971. Boundary Layer Resistance and Temperature Distribution on Still and Flapping Leaves. Plant Physio1. 48:437-442.

32. Partridge, N.L. 1941. Comparative Water Useage and Depth of Rooting of Some Species of Grass. Proc.Amer.Soc.Hort.Sci. 48:426-431. 
33. Penman, H.L. 1948. Natural Evaporation from Open Water, Bare Soil, and Grass. Roy.Soc. London, Proc.Ser.A 193:120-146.

34. Peterson, M.P. 1985. Advances in Nebraska Turfgrass Research: Turfgrass Water Use - Part I. Turfgrass Bu11. Nebraska Turfgrass Foundation, Spring 1985.

35. Pierce, L.T. 1958. Estimating Seasonal and Shortterm Fluctuations in Evapotranspiration from Meadow Crops. Bul1. Am. Meteor. Soc. 39:73-78.

36. Porter, E. 1985. Economic Returns to Irrigation of Kentucky bluegrass and Selected Nursery Crops in Rhode Island. Masters thesis, Univ. of R.I.

37. Providence Water Supply Board 1962. The Providence Water Supply: History, Source, Processing, Distribution.

38. Pruitt, W.O. and D.E. Angus 1961. Comparisons of Evapotranspiration with Solar and Net Radiation and Evaporation from Water Surfaces. First Ann. Rep. USAEPG Contract DA-36-039-SC-80334, 1961, Univ. of Calif., Davis p.74-107.

39. Quackenbush, T.H. and J.T. Phelan 1965. Irrigation Water Requirements of Lawns. J. of Irrig. and Drainage Div. ASCE 91(IR2):11-19. 
40. Salisbury, F.B. and C.W. Ross 1978. Plant Physiology. 2nd ed. Wadsworth Publ.Co.,Bellmont Ca.

41. SAS INstitue Inc. 1982. SAS User's Guide: Statistics Cary, N.C. 584 pp.

42. Scholander P.F., H.T. Hamme1, E.A. Hemmingsen and E.D. Bradstreet 1964. Hydrostatic Pressure and Osmotic Potential in Leaves of Mangroves and Some Other P1ants. Proc.N.A.S. Vo1.52:119-125.

43. Shearman, T. and J.B. Beard 1973. Environmental and Cultural Preconditioning Effects on Water Use Rate of Penncross bentgrass. Crop Sci. 13:424-427.

44. Stanhill, G. 1957. The Effect of Differences in Soil-Moisture Status on Plant Growth: A Review and Analysis of Soil Moisture Regime Experiments. Soil Sci. 84:205-214.

45. Tanner, C.B. 1967. Measurement of Evapotranspir-ation. In R.M. Hagen (ed.) Irrigation of Agricultural Lands: Agronomy II, Madison Wis. ASA p. 534-574.

46. Thornthwaite, C.W. and J.R. Mather 1955. The Water Budget and It's Use in Irrigation. U.S. Dept. Agr. Yearbook of Agric. 1955:346-358.

47. Tovey, R., J. Spencer and S. Muckel 1969. Turfgrass Evapotranspiration. Agron.J. 61:230-234. 
48. Tyree, M.T. and H.T. Hamme1 1972. The Measurement of the Turgor Pressure and the Water Relations of Plants by the Pressure Bomb Technique. J.Exp.

Botany Vol.23 No.24:267-282.

49. Veihmeyer, F.J. and A.H. Hendrickson 1950.

Soil Moisture in Relation to Plant Growth.

Ann.Rev. Plant Physiol. 1:285-304.

50. Veihmeyer, F.J. and A.H. Hendrickson 1955.

Does Transpiration Decrease as the Soil Moisture

Decreases? Trans.Am.Geophys.Union 36:425-448. 